Alejandro W. Bunge

Tribunal of the Roman Rota, Prelate Auditor

\title{
Juan Pablo II y las Conferencias episcopales: comunión y colegialidad
}

\author{
John Paul II and Bishops' Conferences: \\ Communion and Collegiality
}

\begin{abstract}
John Paul II has presented the Bishops' Conference both in his large teaching about bishop's ministry and his legislative role. In his genuine teaching about that, Pope using precise theological and legal terms, strengthen the theological and juridical nature of the Bishops' Conferences. In this article a detailed analysis is made of the first fifteen years of teaching of the Pope John Paul II about the Episcopal Conferences communion and collegiality. The main sources of this paper are Apostolic Letter Apostolos Suos, that clarifies the theological and legal nature of Bishops' Conferences, and Directory for the Pastoral Ministry of Bishops Apostolorum Successores, which refers to Bishops' Conferences as instruments of communion in the Church and alive expression of bishop collegiality at the extent that it is their responsibility.
\end{abstract}

\section{Keywords}

The Bishops' Conferences, bishops collegiality, ecclesial communion, John Paul II.

\section{Introducción}

Al clausurar la II Asamblea General Extraordinaria del Sínodo de los Obispos del año 1985, convocada por el Papa con la finalidad de rememorar la intensa experiencia de colegialidad vivida durante el Concilio Vaticano II y para evaluar los frutos de su aplicación a los veinte años de su clausura, el beato Juan Pablo II acogía e impulsaba el pedido hecho por esta Asamblea de 
estudiar la naturaleza de las Conferencias episcopales, que desarrollan en este tiempo un aporte tan importante a la vida de la Iglesia ${ }^{1}$.

Poco después, hablando a los funcionarios de la Curia Romana, señalaba que, a pesar de las valiosas contribuciones que se habían realizado hasta ese momento, el crecimiento de las estructuras de las Conferencias episcopales y de su influencia en la vida de la Iglesia había hecho aparecer también problemas doctrinales y pastorales, como consecuencia lógica de su desarrollo e importancia ${ }^{2}$.

Ya desde los tiempos de la discusión en el aula Conciliar el debate sobre la naturaleza teológica de las Conferencias episcopales ocupaba a los estudiosos. Podemos destacar, entre otras consecuencias que se desprendían de las diversas maneras de concebir su naturaleza teológica, el distinto alcance que se les atribuía para tomar decisiones vinculantes, es decir, una capacidad jurídica que no habían tenido en sus comienzos en la primera mitad del siglo diecinueve 3 . Se puede decir que "los problemas doctrinales y pastorales" surgidos por la creciente influencia de las Conferencias episcopales en la vida de la Iglesia han impulsado la dedicación de los estudiosos al tema. Pero no se puede dejar de tener en cuenta que estos mismos problemas también frenaron en su momento el avance de la reflexión ${ }^{4}$.

Una vez concluida la Asamblea del Sínodo de los Obispos de 1985, Juan Pablo II encargó a la Congregación para los Obispos la realización del estudio de la cuestión a través de la consulta a las mismas Conferencias episcopales 5 . Después de haber enviado un proyecto sobre el tema ${ }^{6}$, que, al parecer del eminente historiador de las Conferencias episcopales, G. Feliciani, fue ampliamente criticado ${ }^{7}$, hubo que esperar un tiempo

1 Cf. Juan Pablo II, Discurso a los Padres congregados para la Clausura de la Asamblea General Extraordinaria del Sínodo de los Obispos, 07/12/1985, AAS 78 (1986) 435.

2 Cf. Juan Pablo II, Discurso a los que cumplen su ministerio en la Curia Romana, 28/06/1986, AAS 79 (1987) 197.

3 No es este el lugar para presentar una bibliografía completa sobre el tema. Baste citar la que presenta A. Antón en su obra Conferencias episcopales, ¿instancias intermedias?, Salamanca 1989, págs. 15-24.

4 Cf. V. Messori - J. Ratzinger, Rapporto sulla fede, Milano 1985, págs. 59-64.

5 Cf. Juan Pablo, Discurso a los que cumplen su ministerio en la Curia Romana, 28/06/1986, AAS 79 (1987) 197-198.

6 El texto enviado a las Conferencias episcopales como un instrumentum laboris, fechado en Roma el 1 de julio de 1987, fue publicado por Il Regno. Documenti, 33 (1988) 390-396.

7 Cf. G. Feliciani, Il potere normativo delle Conferenze episcopali nella comunione ecclesiale, en ME 116 (1991) 87. Otros autores que se han referido a este instrumentum laboris son: P. López 
de maduración, hasta que el mismo Juan Pablo II, promulgando su Carta Apostólica Apostolos Suos, dio un paso decisivo de carácter magisterial y legislativo que clarifica la naturaleza teológica y jurídica de las Conferencias episcopales ${ }^{8}$.

Un cuidadoso y detallado magisterio precedió la promulgación de esta Carta Apostólica, y también lo continuó. Es lo que pretendemos analizar en este trabajo, así como los contenidos y las consecuencias de sus decisiones. Necesariamente el tema no puede tratarse de manera exhaustiva, ya que ocuparía un espacio indudablemente superior al disponible. Lo haré, de todos modos, de manera suficientemente indicativa, con las referencias suficientes para poner en evidencia que el beato Juan Pablo II realmente comprendió, vivió y enseñó y legisló el ejercicio de dimensiones esenciales del ministerio episcopal, como la comunión y la colegialidad.

Me detendré primero en la naturaleza teológica de las Conferencias episcopales. A la luz de la clave eclesiológica del Concilio, analizaré el uso que Juan Pablo II hace del concepto de comunión eclesial aplicado a las Conferencias episcopales, así como también por qué las interpreta como expresión de la colegialidad, el gran aporte del Concilio a la teología del episcopado (I). Continuaré señalando algunos aportes doctrinales y legislativos que el mismo Papa ha brindado con el Motu Proprio Apostolos Suos, final de un camino recorrido por la doctrina y al mismo tiempo comienzo de un desarrollo que sin dudarlo deberá nutrirse del camino recorrido (II). Me ocuparé a continuación de algunas precisiones que agregó Juan Pablo II en su última Exhortación Apostólica postsinodal, posterior a la Asamblea General Ordinaria del Sínodo de los Obispos sobre el Obispo, servidor del Evangelio de Jesucristo para la esperanza del mundo (III). Por último haré referencia al Directorio para el Ministerio de los Obispos Apostolorum Successores que, sin haber sido formalmente realizado por el amado Papa, fue querido por él y es sin duda fruto de su constante dedicación magisterial y legislativa en la aplicación y concreción de las enseñanzas del Concilio Vaticano II sobre el ministerio episcopal

Gallo, Episcopal conferences: a reply and comment on "Instrumentum laboris", ME 114 (1989) 149176; J. Manzanares, Reflexiones sobre el documento "Estatuto teológico y jurídico de las Conferencias episcopales", REDC 46 (1989) 189202.

8 Cf. Juan Pablo II, Carta Apostólica Apostolos Suos, 21 de mayo de 1998, en AAS 90 (1998) $641-658$. 


\section{The Person and the Challenges \\ 46 \\ I. Comunión y colegialidad en las Conferencias episcopales}

El Código, siguiendo al Concilio, concibe a las Conferencias episcopales como la agrupación de los Obispos de una nación o territorio determinado, que ejercen conjuntamente algunas funciones pastorales respecto a los fieles de ese territorio9.

En sintonía con lo que nos sugiere esta concepción de las Conferencias episcopales avanzada por el Concilio y retomada por el Código de Derecho Canónico, y en sintonía también con toda la eclesiología del Concilio, Juan Pablo II pone el acento en la comunión eclesial y en la colegialidad episcopal al hablar de la naturaleza propia de las Conferencias episcopales. Abordamos ahora estos dos aspectos de la naturaleza eclesiológica de las Conferencias episcopales, según el magisterio de Juan Pablo II.

\section{Conferencias episcopales y comunión eclesial}

Siguiendo al Sínodo Extraordinario de 1985, celebrado a los veinte años de la conclusión del Concilio Vaticano II, Juan Pablo II considera la categoría de la comunión como la idea central y fundamental del mismo Concilio y de su eclesiología ${ }^{10}$. De aquí que resulten tan abundantes las referencias del Papa a la comunión como categoría eclesiológica cuando se refiere al lugar que les corresponde a las Conferencias episcopales dentro de las estructuras eclesiales.

\subsection{Instrumentos de comunión}

El Papa expresa la importancia que le da a esta categoría eclesiológica al considerar la comunión entre los Obispos que la componen como la razón de ser y la primera finalidad de toda Conferencia episcopal, tal como les dice a los Obispos de Brasil durante su visita a Río de Janeiro, y lo repite a los mismos Obispos en su viaje apostólico de $1991^{11}$.

De esta manera, las Conferencias episcopales aparecen como uno de los instrumentos privilegiados para construir la comunión, dice el Papa al Consejo

\footnotetext{
9 Cf. Christus Dominus, n. 37,1 y 38,1, y can. 447.

${ }^{10}$ Cf. Juan Pablo II, Christifideles Laici, n. 19.

${ }^{11}$ Cf. Juan Pablo II, Discurso a Los Obispos de Brasil, en Río de Janeiro, durante su viaje a ese pais, 10/07/1980, AAS 72 (1980) 945-946 y JuAN PABLo II, Discurso a los Obispos de Brasil, en Natal, durante su visita a ese país, 13/10/1991, AAS 84 (1992) 619.
} 
Permanente de la Conferencia episcopal italiana ${ }^{12}$. Esta comunión, por otra parte, es la finalidad misma de la Iglesia, instituida por Jesucristo como signo e instrumento de la comunión de los hombres con Dios y entre si ${ }^{13}$.

Podemos destacar la importancia que tiene para Juan Pablo II la comunión de los Obispos en y a través de la Conferencia episcopal constatando las expresiones de alabanza y agradecimiento que el Papa tiene ante la comunión alcanzada por algunas Conferencias o ante el esfuerzo de otras por alcanzarla. Muchas veces se pronuncia sobre esto, y prácticamente en los mismos términos, como vemos en seguida.

Así, expresa su satisfacción por la comunión que se vive en la Conferencia episcopal de Bolivia, que resulta una premisa indispensable para una pastoral eficaz y sin tensiones comunitarias debilitantes ${ }^{14}$. También expresa su afecto por los esfuerzos de los Obispos de Colombia por mantener y acrecentar la comunión dentro de su Conferencia episcopal ${ }^{15}$. Da gracias a Dios por la comunión eclesial vivida por los Obispos de la Conferencia episcopal del Océano Indico, que hace posible que la misma crezca, con lo que podrá aportar cada vez más su contribución original en favor de la Iglesia Universal ${ }^{16}$. Expresa su aprecio por la voluntad y esfuerzos de un grupo de Obispos de España encaminados a mantener y acrecentar la unidad y comunión en el seno de la Iglesia y de su misma Conferencia episcopa $1^{17}$. Y agradece a los Obispos Alemanes de la región sudoccidental su solicitud por conseguir y afianzar la unidad y la comunión dentro de la Iglesia y en el seno de su Conferencia episcopal ${ }^{18}$.

${ }^{12}$ Cf. Juan Pablo II, Discurso al Consejo Permanente de la Conferencia episcopal italiana, 23/01/1979, AAS 71 (1979) 366.

${ }^{13} C f$. Concilio Vaticano II, Lumen gentium, $\mathrm{n}^{\circ} 1$.

${ }^{14}$ Cf. Juan Pablo II, Discurso a un grupo de Obispos de Bolivia con ocasión de su visita ad limina, 13/11/1980, AAS 72 (1980) 1239.

${ }^{15}$ Cf. Juan Pablo II, Discurso a un grupo de Obispos de Colombia con ocasión de su visita ad limina, 11/06/1985, AAS 77 (1985) 1076.

${ }^{16}$ Cf. Juan Pablo II, Discurso a los Obispos de la Conferencia episcopal del Océano Indico, 29/09/1987, L'Oss. Rom. (1987) 911.

${ }^{17}$ Cf. Juan Pablo II, Discurso al Arzobispo de Barcelona y a los Obispos de las provincias eclesiásticas de Tarragona y Oviedo, España, con ocasión de su visita ad limina, 11/11/1991, AAS 84 (1992) 970.

${ }^{18}$ Cf. Juan Pablo II, Discurso a los Obispos alemanes de la región sudoccidental con ocasión de su visita ad limina, 19/12/1992, L'Oss. Rom. (1993) 8-9. 


\subsection{Naturaleza de esta comunión}

Esta comunión de y en las Conferencias episcopales es, ante todo, una comunión de fe, y es, por lo tanto, una realidad sobrenatural, que no es sólo el resultado de los esfuerzos humanos por construirla, sino que necesita de la gracia, y tiene como fuentes principales la oración y las celebraciones sacramentales. Por esto llama a los Obispos de Holanda a buscar ocasiones de oración y liturgia en común, siguiendo las indicaciones del Documento final del Sínodo particular para Holanda ${ }^{19}$. Y a los Obispos de Chile les dice que la unidad de su Conferencia episcopal será una realidad cada día más palpable si la comunión íntima en la fe y en la caridad penetra todo su ser, su obrar y su ministerio pastoral ${ }^{20}$.

Por lo dicho recién, se comprende que Juan Pablo II ponga los fundamentos de la comunión de los Obispos en el seno de la Conferencia episcopal en el mismo Señor Jesús, que es quien los ha llamado a ser sus ministros, tal como dice prácticamente en los mismos términos a los Obispos de Brasil, cuando los visita en Río de Janeiro en el año 1980, y a los Obispos de Portugal, cuando los visita en el año $1982^{21}$.

El Papa encuentra los principios de la comunión de los Obispos en el seno de una Conferencia episcopal en la antigua fórmula, siempre válida: in necessariis unitas, in dubiis libertas, in omnibus caritas. Basándose en ella dice a los Obispos de Brasil que la unidad en las cosas necesarias es requisito indispensable para que sea legítima la libertad, y condición para la unión de los Obispos en la Conferencia episcopal ${ }^{22}$.

Esta comunión de los Obispos en la Conferencia episcopal es fruto de un servicio humilde y perseverante, el más exigente y delicado, pero también el más precioso e indispensable, porque es el servicio a una dimensión esencial de la Iglesia y a la misión de la misma en el mundo, dice el Papa a un grupo de Obispos de España, recordando un discurso suyo a toda la Conferencia episcopal ${ }^{23}$.

${ }^{19}$ Cf. Juan Pablo II, Discurso a los Obispos de Holanda con ocasión de su visita ad limina, 11/01/1988, L'Oss. Rom. (1988) 104.

${ }^{20}$ Cf. Juan Pablo II, Discurso a un grupo de Obispos de Chile con ocasión de su visita ad limina, 10/03/1989, L’Oss. Rom. (1989) 211.

${ }^{21}$ Cf. Juan Pablo II, Discurso a Los Obispos de Brasil, en Río de Janeiro, durante su viaje a ese pais, 10/07/1980, AAS 72 (1980) 946 y JuAN PABLo II, Discurso a la Conferencia episcopal de Portugal, durante su visita a ese país, 13/05/1982, AAS 74 (1982) 897.

${ }^{22}$ Cf. Juan Pablo II, Discurso a los Obispos de Brasil, en Natal, durante su visita a ese país, 13/10/1991, AAS 84 (1992) 619620.

${ }^{23}$ Cf. Juan Pablo II, Discurso a los Obispos de Barcelona y de las provincias eclesiásticas de Tarragona y Valencia, España, con ocasión de su visita ad limina, 07/11/1986, AAS 79 (1987) 888. 


\subsection{Comunión eclesial y ministerio episcopal}

Esta comunión fraterna de los Obispos en la Conferencia episcopal, que brota de raíces sobrenaturales y sacramentales, tiene, además, a juicio de Juan Pablo II, beneficiosos efectos a la hora del desarrollo de su misión propia.

Los Obispos encuentran en ella, en primer lugar, una ayuda inestimable para enfrentar con mayor facilidad los retos o los desafíos comunes de su ministerio, dice a los de Paraguay ${ }^{24}$. En la mutua comunión dentro de la Conferencia encuentran los Obispos sostén y apoyo para el ejercicio de su ministerio, afirma Juan Pablo II a los Obispos de Lituania ${ }^{25}$. Y dice lo mismo a los Obispos de Grecia, aunque no mencione expresamente a su Conferencia episcopal como el instrumento de esa comunión ${ }^{26}$.

Pero además, la comunión en el seno de su Conferencia episcopal es una exigencia del ministerio pastoral de los Obispos. Todo servicio pastoral de los Obispos, dice Juan Pablo II a los de Brasil, exige primeramente la comunión entre ellos, en el nivel más profundo que se pueda concebir ${ }^{27}$. Prácticamente en los mismos términos se dirige casi dos años después a los Obispos de Portugal $^{28}$. Los objetivos esperados del trabajo de la Conferencia episcopal en la nueva etapa de un camino de reconciliación, dice a los Obispos de Angola y Santo Tomé y Príncipe, requiere una progresiva e intensa comunión entre sus miembros ${ }^{29}$.

\subsection{Efectos de esta comunión}

La comunión de los Obispos dentro de su Conferencia episcopal lleva a superar los particularismos y los partidismos, las disputas entre diversos grupos, de los que debería librarse siempre toda Conferencia, y hace integrar

${ }^{24}$ Cf. Juan Pablo II, Discurso a los Obispos de Paraguay con ocasión de su visita ad limina, 25/09/1979, AAS 71 (1979) 14081409.

${ }^{25}$ Cf. Juan Pablo II, Discurso a los Obispos de Lituania con ocasión de su visita ad limina, 18/04/1988, AAS 80 (1988) 1445.

${ }^{26}$ Cf. Juan Pablo II, Discurso a los Obispos de Grecia con ocasión de su visita ad limina, 27/01/1989, AAS 81 (1989) 928.

${ }^{27}$ Cf. Juan Pablo II, Discurso a Los Obispos de Brasil, en Río de Janeiro, durante su viaje a ese pais, 10/07/1980, AAS 72 (1980) 946.

${ }^{28}$ Cf. Juan Pablo II, Discurso a la Conferencia episcopal de Portugal, durante su visita a ese pais, 13/05/1982, AAS 74 (1982) 897.

${ }^{29}$ Cf. Juan Pablo II, Discurso a los Obispos de Angola y Santo Tomé y Príncipe con ocasión de su visita ad limina, 05/09/1991, AAS 84 (1992) 576. 
The Person and the Challenges
Volume 3 (2013) Number 1

dentro de un saludable pluralismo las comprensibles diversidades, dice Juan Pablo II a los Obispos de Brasil ${ }^{30}$.

Además, de la íntima comunión y el intercambio fraterno entre los Obispos en la Conferencia episcopal brotan muchos frutos de coordinación pastoral, para el bien de cada una de las Iglesias particulares y para la tarea apostólica en conjunto en el ámbito de la Conferencia, dice el Papa a los Obispos de Panamá ${ }^{31}$.

La comunión de los pastores dentro de la Conferencia episcopal, dice Juan Pablo II a un grupo de Obispos de Brasil reunido con sus colaboradores en el encuentro de diálogo por él convocado en el Vaticano, debe servir de fundamento para la comunión de todos los fieles de la Iglesia, de modo que ésta sea y se manifieste delante de la comunidad humana como un sacramento de comunión ${ }^{32}$. Así, la unidad de los pastores se convierte en la raíz de la comunión eclesial, dice el Papa a los Obispos de Hungría ${ }^{33}$.

Los efectos de la comunión de los Obispos en una Conferencia episcopal no se agotan en las repercusiones eclesiales, sino que llegan incluso a la misma sociedad. Así lo dice Juan Pablo II, por ejemplo, a los Obispos de Bélgica, país donde nacieron las Conferencias episcopales ${ }^{34}$.

A juicio de Juan Pablo II, los encuentros de la Conferencia episcopal resultan útiles y necesarios para crear la mentalidad y la atmósfera de comunión y comunidad que propone la Conferencia episcopal italiana dentro del plan pastoral para la década del noventa, y conviene, por lo tanto potenciarlos. Y una comprensión más profunda del don de la comunión, cita el Papa a los Obispos de esta Conferencia episcopal, hará crecer en toda la Iglesia de ese lugar el don de la caridad y hará creíble el anuncio evangélico que ella es llamada a realizar ${ }^{35}$.

${ }^{30}$ Cf. Juan Pablo II, Discurso a Los Obispos de Brasil, en Río de Janeiro, durante su viaje a ese pais, 10/07/1980, AAS 72 (1980) 947.

${ }^{31}$ Cf. Juan Pablo II, Discurso a los Obispos de Panamá con ocasión de su visita ad limina, 17/11/1983, AAS 76 (1984) 407.

${ }^{32}$ Cf. Juan Pablo II, Discurso a los Cardenales y un grupo de Arzobispos y Obispos de Brasil al comenzar el encuentro de diálogo en el Vaticano, 13/03/1986, AAS 78 (1986) 1041-1042.

${ }_{33}$ Cf. Juan Pablo II, Discurso a los Obispos de Hungría con ocasión de su visita ad limina, 13/11/1987, AAS 80 (1988) 651.

${ }^{34}$ Cf. Juan Pablo II, Discurso a los Obispos de Bélgica, en Malinas, durante su visita a ese país, 18/05/1985, L'Oss. Rom. (1985) 358.

${ }^{35}$ Cf. Juan Pablo II, Discurso a los Obispos del Lacio, Italia, con ocasión de su visita ad limina, 05/11/1981, AAS 74 (1982) 21-22. 
Afrontar juntos los principales problemas pastorales que afectan a la vida de la Iglesia y ejercer también en conjunto la misión profética, especialmente en lo referente a las cuestiones referentes al orden social a las que tienen que dar respuesta a la luz del evangelio, son formas concretas en las que se implementa la comunión eclesial que viven los Obispos en el seno de una Conferencia, dice Juan Pablo II a los Obispos de la Conferencia episcopal de Papúa Nueva Guinea e Islas Salomón en la parroquia de San José de Port Moresby, durante su visita a ese país ${ }^{36}$.

No sólo las Conferencias episcopales sino también los organismos internacionales a través de los cuales ponen en común sus esfuerzos apostólicos los Obispos pertenecientes a varias Conferencias episcopales son considerados por Juan Pablo II instrumentos aptos para vivir y construir la comunión eclesial. Así, hablando en Costa Rica ante los Obispos de América Central, considera al Secretariado Episcopal de América Central y al Consejo Episcopal Latinoamericano como importantes formas de comunión pastoral para un fecundo trabajo en las Iglesias ${ }^{37}$. Recuerda el encuentro con los participantes del VI Simposio del Consejo de las Conferencias episcopales de Europa como una fuerte experiencia de comunión eclesial ${ }^{38}$. Dirigiéndose a los presidentes de estas Conferencias episcopales, pone la comunión de los Obispos entre sí y con el sucesor de Pedro y de los episcopados como tarea a la que debe dedicarse este Consejo ${ }^{39}$.

\section{La colegialidad episcopal en las Conferencias episcopales}

Al menos en dos ocasiones el Papa aplica el término "Colegio" a una Conferencia episcopal. Lo hace hablando a los Obispos de Mozambique, en $1982^{40}$, y posteriormente dirigiéndose a los de Checoslovaquia, en 1990. En esta

${ }^{36}$ Cf. Juan Pablo II, Discurso a los Obispos de la Conferencia episcopal de Papúa Nueva Guinea e Islas Salomón en la parroquia de San José de Port Moresby, durante su visita a ese país, 08/05/1984, AAS 76 (1984) 1012-1013.

${ }^{37}$ Cf. Juan Pablo II, Discurso a los Obispos de América Central en Costa Rica, durante su visita a ese país, 02/03/1983, AAS 75 (1983) 700.

${ }^{38}$ Cf. Juan Pablo II, Mensaje a los Presidentes de las Conferencias episcopales de Europa, 02/01/1986, AAS 78 (1986) 454.

${ }^{39}$ Cf. Juan Pablo II, Discurso a la Asamblea de los Presidentes de las Conferencias episcopales europeas, 01/12/1992, L'Oss. Rom. (1992) 720.

${ }^{40}$ Cf. Juan Pablo II, Discurso a los Obispos de Mozambique con ocasión de su visita ad limina, 23/09/1982, AAS 74 (1982) 1226. 
ocasión utiliza repetidamente el término ${ }^{41}$. No alcanzan, por supuesto, estas expresiones, para afirmar que el Papa entiende las Conferencias episcopales como órganos de la colegialidad episcopal, pero sí para atestiguar desde un comienzo que Juan Pablo II no tiene temores de usar este término, del que, como veremos seguidamente, define con claridad su alcance y significado cuando se utiliza en relación a las Conferencias episcopales.

El Papa menciona a las Conferencias episcopales, junto a otras estructuras colegiales de carácter internacional o continental, cuando en su primera encíclica intenta exponer el desarrollo que ha tomado a lo largo de la historia la colegialidad episcopal $^{42}$. Y a los Obispos de la Conferencia episcopal de Alto Volta les dice que ellos viven entre ellos mismos la colegialidad, que es un elemento estructural de la Iglesia al que en nuestro tiempo, siguiendo una importante enseñanza del Concilio, se concede especial importancia, y que debe entenderse como un modo de gobierno del episcopado. De este modo, les dice Juan Pablo II, experimentan ciertamente día a día la gran ayuda que les significa para el desarrollo de su ministerio pastoral y tienen motivos para esperar el aumento de su eficacia. Sin embargo, continúa el Papa, no son sólo razones prácticas, sino espirituales y teológicas, las que dan fundamento a esta colegialidad como elemento estructural de la Iglesia, vivido en la Conferencia episcopal ${ }^{43}$.

Por lo tanto, es claro que para Juan Pablo II las Conferencias episcopales son ciertamente una estructura eclesial que expresan un elemento teológico que forma parte de la naturaleza misma de la Iglesia, como es la colegialidad. Así, a pesar de tener las Conferencias episcopales con su actual configuración una historia reciente, que se inicia con la primera reunión del episcopado belga en Malinas en el año 1830, el Papa ve realizado en ellas un elemento que pertenece a la esencia misma del ministerio episcopal desde sus orígenes ${ }^{44}$.

Por supuesto, no se trata aquí de la colegialidad entendida como la cualidad de una corporación de personas de una misma dignidad o profesión, sino la propia del Colegio episcopal, sucesor del Colegio apostólico, que hace referencia a una propiedad teológica que le corresponde desde su fundación por el mismo

${ }^{41}$ Cf. Juan Pablo II, Discurso a los Obispos de la Conferencia episcopal Checoslovaca, 21/04/1990, L’Oss. Rom. (1990) 232.

${ }^{42}$ Cf. Juan Pablo II, Carta Encíclica Redemptor hominis, 04/03/1979, AAS 71 (1979) 264-265.

${ }^{43}$ Cf. Juan Pablo II, Discurso a la Conferencia episcopal de Alto Volta, durante su viaje a ese país, 10/05/1980, L'Oss. Rom. (1980) 306.

${ }^{44}$ Cf. Concilio Vaticano II, Lumen Gentium, ${ }^{\circ} 22$. 
Jesucristo $^{45}$. Veamos con más detalle, a la luz del magisterio de este Papa, la relación entre las Conferencias episcopales y la colegialidad episcopal.

Ante los Obispos de Vietnam, que se han reunido primero por provincias y después en la Conferencia episcopal para preparar su visita ad limina del año 1980, Juan Pablo II señala a las Conferencias episcopales como un signo de la colegialidad, y un modo concreto en que ésta se realiza ${ }^{46}$. Ellas tienen entre sus objetivos, dice en otra oportunidad a los Obispos de Portugal, el de constituir un espacio de encuentro en la vivencia de la colegialidad efectiva y afectiva ${ }^{47}$. Y hablando a los Cardenales, Prelados y Oficiales de la Curia Romana en las vísperas de la solemnidad de San Pedro y San Pablo del año 1980, el Papa pone a las Conferencias episcopales entre las formas en las que hoy se expresa el iunctim, que constituye el punto de contacto entre el carácter colegial del ministerio episcopal y el carácter primacial que le corresponde al sucesor de Pedro en el ejercicio del ministerio pastoral en la Iglesia ${ }^{48}$.

Quiere decir que las Conferencias episcopales son para Juan Pablo II un signo y a la vez un modo concreto de realizarse la colegialidad episcopal. Constituyen un espacio de encuentro entre los Obispos en el que experimentan la vivencia de la colegialidad efectiva y afectiva, y son también de ese modo un lugar de encuentro entre los Obispos, que ejercen un ministerio que es por su misma naturaleza colegial, y el Papa, que es la cabeza de todo el Colegio episcopal, como Pedro lo fue del Colegio apostólico. Todo esto muestra que la colegialidad que encontramos en las Conferencias episcopales es algo más que el carácter colegial de todo grupo en el que las decisiones se toman con la participación de sus miembros ${ }^{49}$, y que tiene que ver con una dimensión teológica propia del ministerio episcopal.

\subsection{Qué colegialidad hay en las Conferencias}

Esta colegialidad, que se vive en el interior de las Conferencias episcopales y en la relación entre ellas y el Papa, es una colegialidad efectiva y afectiva, dice

${ }^{45}$ Cf. Concilio Vaticano II, Nota Praevia de la Lumen Gentium, $1^{\text {a }}$.

${ }^{46}$ Cf. Juan Pablo II, Discurso a un grupo de Obispos de Vietnam con ocasión de su visita ad limina, 17/06/1980, AAS 72 (1980) 632.

${ }^{47}$ Cf. Juan Pablo II, Discurso a los Obispos de la provincia eclesiástica de Braga, Portugal, con ocasión de su visita ad limina, 04/02/1983, AAS 75 (1983) 489.

${ }^{48}$ Cf. Juan Pablo II, Discurso a los Cardenales, Prelados y Oficiales de la Curia Romana, 28/06/1980, AAS 72 (1980) 647.

${ }^{49}$ Cf. can. $115 \S 2$. 
Juan Pablo II a los Obispos de Francia utilizando los términos del Concilio, que comenzó alrededor de Cristo, en la comunión de los doce apóstoles ${ }^{50}$. Es la misma colegialidad, por lo tanto, que se vive al interior de todo el colegio episcopal, sucesor del colegio de los apóstoles.

Las Conferencias episcopales aparecen así ante Juan Pablo II como una concreción local de la colegialidad de los Obispos, según afirma ante los Obispos de Mozambique durante su visita ad limina del año $1988^{51}$. Esta expresión de la colegialidad que se vive en las Conferencias episcopales, tal como han sido definidas por el Concilio y encuadradas jurídicamente en el Código de Derecho Canónico, deriva de la misma misión que recibe un Obispo cuando es injertado en el Colegio episcopal, dice en otra ocasión el Papa a los Obispos de Brasil ${ }^{52}$. Y en el intercambio de pareceres que realizan los Obispos dentro de la Conferencia episcopal, continúa diciendo Juan Pablo II en la misma ocasión, está siempre subyacente la colegialidad episcopal efectiva y afectiva de los sucesores de los apóstoles ${ }^{53}$.

El Papa recuerda a los Obispos del Brasil que la suya es una de las primeras Conferencias episcopales, nacida antes del Concilio, que las proclamó como una expresión peculiar y un órgano particularmente apropiado de la colegialidad episcopal sobre cuya doctrina el mismo Concilio puso nueva luz ${ }^{54}$. Y refiriéndose a la colaboración desarrollada entre los Obispos de Estados Unidos a través de la Conferencia episcopal para apoyar a los religiosos, conforme al encargo que les había dado él mismo, les dice que no es sólo un medio para realizar ese apoyo que el Papa les ha pedido, es decir, una cuestión meramente operativa, sino un verdadero ejercicio de la colegialidad ${ }^{55}$.

La actividad de la Conferencia episcopal de Papúa Nueva Guinea e Islas Salomón, que es considerada por el Papa como una actividad colegial que

${ }^{50}$ Cf. Juan Pablo II, Discurso a la Conferencia episcopal de Francia, durante su visita a ese pais, 01/06/1980, AAS 72 (1980) 723.

${ }^{51}$ Cf. Juan Pablo II, Discurso a los Obispos de Mozambique con ocasión de su visita ad limina, 15/04/1988, AAS 80 (1988) 1428.

${ }^{52}$ Cf. Juan Pablo II, Discurso a los Obispos de la provincia eclesiástica de Porto Alegre y regional Surtres, de Brasil, con ocasión de su visita ad limina, 16/02/1985, AAS 77 (1985) 818.

${ }^{53}$ Cf. Juan Pablo II, Discurso a los Obispos de la provincia eclesiástica de Porto Alegre y regional Surtres, de Brasil, con ocasión de su visita ad limina, 16/02/1985, AAS 77 (1985) 818.

${ }^{54}$ Cf. Juan Pablo II, Discurso a Los Obispos de Brasil, en Rio de Janeiro, durante su viaje a ese pais, 10/07/1980, AAS 72 (1980) 945.

${ }^{55}$ Cf. Juan Pablo II, Discurso a un grupo de Obispos de Estados Unidos con ocasión de su visita ad limina, 19/09/1983, L'Oss. Rom. (1983) 681. 
los Obispos deben desarrollar y que él mismo alienta, está relacionada con el celo pastoral por la misión universal que han recibido como sucesores de los apóstoles $^{56}$.

También en la relación entre las diferentes Conferencias episcopales, dice Juan Pablo II a los Obispos de Checoslovaquia, encuentran los Obispos una aplicación concreta del afecto colegial mencionado por el Concilio cuando habla de las Conferencias episcopales en la constitución dogmática sobre la Iglesia ${ }^{57}$.

De todos modos, la colegialidad en sentido estricto, dice el Papa a los Obispos de Suiza, es más que la mutua colaboración de los Obispos en una Conferencia. La colegialidad en sentido estricto une a todos los Obispos entre sí y alrededor del Sucesor de Pedro. Por esta razón, cuando se habla de colegialidad en una Conferencia episcopal, debe tenerse en cuenta la responsabilidad que los Obispos de dicha Conferencia episcopal tienen con todo el colegio episcopal; en realidad, las declaraciones oficiales, las acciones, las orientaciones de los Obispos en una Conferencia episcopal, su manera de ejercer el ministerio episcopal en una nación, sigue el Papa, afectan al compromiso pastoral de todo el Colegio episcopal ${ }^{58}$.

A la luz de estos textos, queda claro que cuando Juan Pablo II se refiere a la colegialidad episcopal de las Conferencias episcopales, lo hace considerando la colegialidad que proviene de la naturaleza misma del colegio apostólico y del colegio episcopal.

Pero teniendo en cuenta la última cita que hemos presentado, hay que concluir, siguiendo el pensamiento de Juan Pablo II, que aunque la colegialidad que viven los Obispos dentro de sus Conferencias episcopales sea de la misma naturaleza que la colegialidad de todo el Colegio episcopal, no se puede pensar que se viva dentro de una Conferencia episcopal todo el contenido de la colegialidad episcopal, sino sólo una parte de ella. Podemos decir, ya con nuestras palabras y no con las del Papa, que en las Conferencias episcopales se participa, en forma limitada y parcial, la colegialidad episcopal.

${ }^{56}$ Cf. Juan Pablo II, Discurso a los Obispos de la Conferencia episcopal de Papúa Nueva Guinea e Islas Salomón en la parroquia de San José de Port Moresby, durante su visita a ese pais, 08/05/1984, AAS 76 (1984) 1011-1012.

${ }^{57}$ Cf. Juan Pablo II, Discurso a los Obispos de la Conferencia episcopal Checoslovaca, 21/04/1990, L’Oss. Rom. (1990) 232.

${ }^{58}$ Cf. Juan Pablo II, Discurso a los Obispos de Suiza, en la Abadía de Einsielden, durante su visita a ese pais, 15/06/1984, AAS 77 (1985) 54. 


\subsection{Colegialidad y ministerio episcopal}

Es propio del ministerio de los Obispos un espíritu colegial que los lleva a ir más allá de las estrictas responsabilidades del oficio canónico que se les ha encomendado. Juan Pablo II se refiere con cierta frecuencia a este espíritu colegial que se debe vivir también en las Conferencias episcopales.

El espíritu colegial, vivido en la Conferencia episcopal, resulta necesario para lograr el bien común al que se deben los Obispos, un bien común que no resulta alcanzado de una vez para siempre, sino que debe ser buscado constantemente, dice Juan Pablo II a los Obispos de Bangladesh ${ }^{59}$. El espíritu colegial y la unidad de los Obispos de Panamá en su Conferencia episcopal, dice el Papa, no sólo da mayor vigor a su ministerio, sino que, además, hace más eficaz su acción pastoral ${ }^{60}$.

Pero yendo más allá de un mero espíritu colegial vivido por los Obispos en las Conferencias episcopales, el Papa avanza afirmando el carácter estrictamente colegial que tiene el ejercicio del ministerio episcopal, a través de estas estructuras eclesiales.

El Concilio, proponiendo de nuevo la antigua doctrina de la colegialidad, ha querido dar relieve a las Conferencias episcopales, a través de las cuales los Obispos pueden trabajar unidos por el bien de sus Iglesias particulares, recuerda el Papa a los Obispos de Lituania ${ }^{61}$. De donde se puede esperar que este aspecto colegial del ministerio de los Obispos, rescatado por el Concilio, sea el que inspire el trabajo de una Conferencia episcopal, dice el Papa a los Obispos latinos de la región árabe ${ }^{62}$.

Los Obispos mismos deben vivir una fraternidad en Cristo, dice a los de Nigeria, con todas sus manifestaciones colegiales, a través de las cuales llevan adelante su oficio de santificar, enseñar y regir a su pueblo, brindándose el apoyo unos a otros ${ }^{63}$. Esta fraternidad en Cristo que tienen que vivir los

59 Cf. Juan Pablo II, Discurso a los Obispos de Bangladesh con ocasión de su visita ad limina, 03/09/1985, AAS 78 (1986) 18-19.

${ }^{60}$ Cf. Juan Pablo II, Discurso a los Obispos de Panamá con ocasión de su visita ad limina, 30/01/1989, L’Oss. Rom. (1989) 115.

${ }^{61}$ Cf. Juan Pablo II, Discurso a los Obispos de Lituania con ocasión de su visita ad limina, 18/04/1988, AAS 80 (1988) 1444-1445.

62 Cf. Juan Pablo II, Discurso a los Obispos latinos de la Región Arabe con ocasión de su visita ad limina, 03/02/1989, AAS 81 (1989) 935.

${ }^{63}$ Cf. Juan Pablo II, Discurso a un grupo de Obispos de Nigeria con ocasión de su visita ad limina, 26/09/1987, AAS 80 (1988) 255-256. 
Obispos no es algo agregado "desde afuera" a su ministerio, sino que forma parte intrínsecamente del mismo, ya que los apóstoles, y con ellos los Obispos, han sido llamados a su ministerio a modo de colegio ${ }^{64}$.

Los Obispos de la Conferencia episcopal de Gabón son animados por Juan Pablo II a unir sus esfuerzos para llevar adelante sus responsabilidades como Obispos en una colegialidad siempre más profunda, que es a la vez efectiva y afectiva ${ }^{65}$. No se está refiriendo el Papa sólo a las responsabilidades que tienen en común, sino a todas sus responsabilidades como Obispos, por lo tanto también a las que cada uno tiene conforme a su propio oficio, al frente de una Iglesia particular o como auxiliar de otro Obispo que la preside.

Juan Pablo II tendrá en cuenta la existencia de una estricta responsabilidad colegial, que hace que los Obispos deban enfrentar en conjunto algunos aspectos de su ministerio. Juan Pablo II llama la atención de los Obispos de Estados Unidos sobre la responsabilidad colegial que tienen en relación al estado de vida religiosa en su país, cuando les propone ocuparse de su cuidado y atención a través de la Conferencia episcopal ${ }^{66}$. Y también el problema de las vocaciones en su Iglesias particulares es enfrentado en conjunto por los Obispos de Estados Unidos, recuerda el Papa, con un espíritu de responsabilidad colegial ${ }^{67}$.

La tarea de coordinación y unidad, por la que se alientan y coordinan con eficacia los diversos carismas y ministerios que el Espíritu Santo distribuye en el Pueblo de Dios, encuentra su apoyo en el sentido de responsabilidad colegial que los Obispos de Filipinas manifiestan a través de las reuniones y actividades de la Conferencia episcopal, dice Juan Pablo II a un grupo de ellos ${ }^{68}$. También en el marco de las agrupaciones de Conferencias episcopales en el orden continental los Obispos ejercen una responsabilidad colegial, por ejemplo en el Consejo de Conferencias episcopales de Europa, dice el Papa ${ }^{69}$.

${ }^{64}$ Cf. Concilio Vaticano II, Lumen gentium, ${ }^{\circ} 19$.

${ }^{65}$ Cf. Juan Pablo II, Discurso a los Obispos de Gabón, durante su visita a ese país, 18/02/1982, AAS 74 (1982) 636.

${ }^{66}$ Cf. Juan Pablo II, Discurso a un grupo de Obispos de Estados Unidos con ocasión de su visita ad limina, 19/09/1983, L'Oss. Rom. (1983) 681.

${ }^{67}$ Cf. Juan Pablo II, Mensaje a los Obispos de Estados Unidos, 14/05/1986, AAS 79 (1987) 204.

${ }^{68}$ Cf. Juan Pablo II, Discurso a los Obispos de las regiones de Luzón Norte y Bikol, de Filipinas, con ocasión de su visita ad limina, 25/10/1985, L’Oss. Rom. (1985) 801.

${ }^{69}$ Cf. Juan Pablo II, Discurso a los representantes de las Conferencias episcopales europeas, en Subiaco, 28/09/1980, L'Oss. Rom. (1980) 695. 
De donde se ve que en la mente de Juan Pablo II la colegialidad propia del colegio episcopal es una realidad que hunde sus raíces en el mismo ministerio episcopal. En realidad, teniendo el ministerio episcopal este carácter colegial, toda función propiamente episcopal tiene un carácter colegial, porque cada Obispo actúa siempre y necesariamente como miembro del colegio episcopal del que forma parte y con el que está en comunión. Con más razón, entonces, cuando se trata de la acción de varios Obispos realizada conjuntamente a través de una Conferencia episcopal, será una acción colegial, en cuanto que compromete a legítimos miembros del colegio episcopal en comunión con el resto del colegio y con su cabeza, el Papa.

\subsection{Efectos de esta colegialidad}

La actividad colegial de una Conferencia episcopal tendrá siempre a su base la santidad, afirma Juan Pablo II ante la Conferencia episcopal de Ghana, que es, por otra parte, la gran prioridad de la vida de los Obispos ${ }^{70}$. A su vez, esta colegialidad episcopal, junto con la responsabilidad compartida, fruto del Bautismo, estará a la base de la solidaridad, tan necesaria en naciones con diócesis muy vastas, con una especial necesidad de evangelización y catequesis, como Canadá, decía Juan Pablo II a sus Obispos ${ }^{71}$. Así la colegialidad, inspirada en Cristo, centro de la communio eclesial, se convierte en una escuela de virtudes humanas y sobrenaturales para los Obispos que forman parte de un cuerpo episcopal que la vive, dice Juan Pablo II a un grupo de Obispos de Colombia ${ }^{72}$.

Por otra parte, una manifestación pública de una Conferencia episcopal, dice el Papa a los Obispos de Brasil, produce tanto más impacto cuanto más refleja la unidad, que es el alma de la colegialidad episcopal ${ }^{73}$. Y la unidad colegial de los Obispos en su Conferencia episcopal, dice a los de Polonia, resulta un apoyo para los Obispos, sobre todo en el momento de

${ }^{70}$ Cf. Juan Pablo II, Discurso a los Obispos de Ghana con ocasión de su visita ad limina, 12/11/1981, AAS 74 (1982) 32.

${ }^{71}$ Cf. Juan Pablo II, Discurso a un grupo de Obispos de Canadá con ocasión de su visita ad limina, 30/09/1983, AAS 76 (1984) 357-358.

${ }^{72}$ Cf. Juan Pablo II, Discurso a un grupo de Obispos de Colombia con ocasión de su visita ad limina, 04/12/1989, AAS 82 (1990) 702.

${ }^{73}$ Cf. Juan Pablo II, Discurso a Los Obispos de Brasil, en Río de Janeiro, durante su viaje a ese pais, 10/07/1980, AAS 72 (1980) 946. 
las dificultades ${ }^{74}$. A los Obispos de Uruguay les recuerda que tienen que potenciar la dimensión colegial de su labor como Conferencia episcopal para poder desarrollar con mayor eficacia y adaptación a la realidad las tareas que corresponden a la Conferencia ${ }^{75}$.

La consolidación del sentido colegial dentro de la Conferencia episcopal da vigor al ministerio de los Obispos, y permite una mejor adaptación a las realidades pastorales, dice Juan Pablo II a los Obispos de Puerto Rico ${ }^{76}$. El consenso colegial dentro de la Conferencia, al igual que el consenso con el resto de sus hermanos en el episcopado, permitirá a los Obispos de Alemania, les dice Juan Pablo II, cumplir las graves tareas que les corresponden ${ }^{77}$.

Señalemos por último algunos campos concretos mencionados por el Papa, en los que se pone de manifiesto la acción colegial de las Conferencias episcopales. Juan Pablo II señala varios campos específicos en los que los Obispos de Kenia trabajan colegialmente en su Conferencia episcopal, por ejemplo las vocaciones sacerdotales y religiosas, la promoción de la familia, la inculturación del mensaje del evangelio, la promoción del desarrollo a través de la educación y los servicios sociales, el establecimiento de comunidades cristianas, la atención del problema de los refugiados, la búsqueda de recursos y la acción conjunta para enfrentar problemas varios ${ }^{78}$. A los Obispos de Zaire les recuerda también diversos campos donde el trabajo colegial necesita de las Asambleas generales y de la ayuda de eventuales secretariados que estén a su servicio y de todos los Obispos que forman la Conferencia episcopal: la teología, la liturgia, la ética familiar, la escuela ${ }^{79}$. Y en especial, hablando al Consejo de la Secretaría General del Sínodo de los Obispos el Papa se refiere al esfuerzo colegial de los Obispos en la preparación de las Asambleas del Sínodo de los Obispos. Cuanto mayor sea el trabajo colegial en la preparación

${ }^{74}$ Cf. Juan Pablo II, Discurso a la Asamblea plenaria del Episcopado polaco, en Jasna Góra, durante su visita a ese pais, 19/06/1983, L'Oss. Rom. (1983) 362.

${ }^{75}$ Cf. Juan Pablo II, Discurso a los Obispos de Uruguay con ocasión de su visita ad limina, 14/01/1985, AAS 77 (1985) 659.

${ }^{76}$ Cf. Juan Pablo II, Discurso a los Obispos de Puerto Rico con ocasión de su visita ad limina, 27/10/1988, AAS 81 (1989) 598-599.

77 Cf. Juan Pablo II, Discurso a los Obispos alemanes de la región sudoccidental con ocasión de su visita ad limina, 19/12/1992, L'Oss. Rom. (1993) 8.

${ }^{78}$ Cf. Juan Pablo II, Discurso a los Obispos de Kenia con ocasión de su visita ad limina, 06/12/1982, AAS 75 (1983) 151-152.

${ }^{79}$ Cf. Juan Pablo II, Discurso a un grupo de Obispos de Zaire con ocasión de su visita ad limina, 12/04/1983, AAS 75 (1983) 621. 
de estas Asambleas, en las Iglesias particulares y en las Conferencias episcopales, mayor es el fruto que se puede esperar de las mismas ${ }^{80}$.

De todo esto concluimos que para Juan Pablo II, coherentemente con el origen de esta colegialidad de las Conferencias episcopales en la misma naturaleza del colegio episcopal y del colegio apostólico, los efectos de su realización práctica redundan en una mayor eficacia del ministerio de los Obispos.

\section{Conclusiones sobre comunión y colegialidad en las Conferencias episcopales}

Digamos en primer lugar que, aunque el ministerio de Juan Pablo II en la Sede de Pedro abarca unos cuantos años, no hemos podido percibir en los pronunciamientos realizados a lo largo del mismo ningún cambio sustancial en su modo de concebir la comunión eclesial y la colegialidad de las Conferencias episcopales. Sus afirmaciones, sin ser siempre las mismas, son similares o equivalentes, y ponen en evidencia un pensamiento coherente y uniforme a través de todos los pronunciamientos analizados.

También es importante destacar que, aún dirigiéndose a Conferencias episcopales muy distintas, unas de muchos miembros, otras de pocos, algunas con muchos años de funcionamiento, otras muy recientes, unas con estructuras muy evolucionadas y otras muy precarias, más allá de las lógicas diferencias de acentos en lo que dice a cada una, siempre se encuentra a la base una concepción única de las Conferencias episcopales.

Veamos primero lo que se refiere a la comunión eclesial. Como recordábamos, Juan Pablo II encuentra en la comunión la clave eclesiológica del Concilio Vaticano II $^{81}$. Pero además, podemos tener en cuenta con el Concilio que la comunión es la razón misma de ser de la Iglesia, querida por Dios como sacramento, es decir, signo e instrumento de la comunión de los hombres con Dios y de los hombres entre $\mathrm{si}^{82}$.

La Iglesia es precisamente este misterio de comunión que nace de la iniciativa de Dios, se realiza en el misterio pascual y se expande a través del tiempo y del espacio por la acción de la gracia divina y el ministerio de la Iglesia.

${ }^{80}$ Cf. Juan Pablo II, Discurso a los miembros del Consejo de la Secretaría General del Sínodo de los Obispos, 30/04/1983, AAS 75 (1983) 650-651.

\footnotetext{
81 Cf. nota 10.

${ }^{82}$ Cf. nota 13 .
} 
Se comprende entonces que las Conferencias episcopales, tal como las entiende Juan Pablo II como instrumentos de la comunión eclesial, aunque no pertenezcan por su propia naturaleza a la constitución divina de la Iglesia, están sin embargo relacionadas con un elemento constitutivo e imprescindible de la misma.

La Iglesia existió durante muchos siglos sin las Conferencias episcopales, pero no existió nunca sin la comunión, ya que ella es precisamente una comunión visible y sobrenatural, es decir, sacramental, de los hombres con Dios y de los hombres entre sí. Hoy, a la luz de la constatación hecha por los padres en el Concilio Vaticano II, las Conferencias episcopales resultan un instrumento útil para realizar, afianzar y acrecentar la comunión de la Iglesia. Por eso Juan Pablo II identifica esta comunión eclesial con la razón de ser y la finalidad primera de las Conferencias episcopales. Podría suceder que el día de mañana las Conferencias episcopales no resulten útiles o fueran menos eficaces para la construcción de la comunión eclesial, como hoy resultan menos prácticos algunos instrumentos de la comunión que en otros siglos fueron imprescindibles, como los Sínodos provinciales. En ese momento podrá prescindirse de las Conferencias episcopales, pero no podrá prescindirse de la comunión eclesial, y deberán surgir otros instrumentos que cubran la labor que hoy éstas realizan.

La profundización de la eclesiología de comunión, rescatada por el Concilio de una cierta sombra en la que había quedado para la teología de occidente, es, entonces, el marco adecuado para profundizar el estudio de la naturaleza eclesiológica de las Conferencias episcopales. Juan Pablo II no realiza grandes avances por este camino, pero sí da pistas firmes que invitan a realizar nuevos intentos de avanzar en la profundización de la naturaleza eclesiológica de las Conferencias episcopales. Así, por ejemplo, identificando a Jesús como el fundamento de la comunión entre los Obispos en las Conferencias episcopales y señalando el carácter sobrenatural y sacramental de la comunión que en ellas viven, previene contra una comprensión meramente utilitaria de las Conferencias episcopales, para situarlas debidamente en su relación con un elemento esencial de la Iglesia, como es la comunión.

Las Conferencias episcopales tendrán también un aspecto utilitario, que el Papa no deja de considerar, ya que producen innumerables frutos en el orden de la realización del ministerio episcopal y de la misión de la Iglesia. Juan Pablo II lo menciona repetidamente, como vimos al analizar sus afirmaciones sobre los frutos de la comunión de las Conferencias episcopales. Pero este sentido utilitario de las Conferencias episcopales no debe oscurecer, sino por 
el contrario iluminar el estudio de su naturaleza eclesial para lo que resulta una clave preciosa la eclesiología de comunión.

Incluso para el estudio y la evolución de la naturaleza canónica de las Conferencias episcopales no bastará limitarse a los aspectos prácticos de su funcionamiento y capacidad jurídica, sino que habrá que tener debidamente en cuenta sus fundamentos eclesiológicos, en especial sus raíces en la teología de comunión, para que se avance cada vez más y mejor en la línea, señalada por el Concilio y evidenciada por Juan Pablo II, que hace de las Conferencias episcopales útiles instrumentos para la misión de la Iglesia, y en particular para realizar la comunión ${ }^{83}$.

Entre los grandes aportes del Concilio Vaticano II a la eclesiología hay que ubicar su clara afirmación de la sacramentalidad de este grado del sacramento del orden y la colegialidad del episcopado ${ }^{84}$.

El ministerio episcopal es por su misma naturaleza colegial, ya que los apóstoles fueron llamados a modo de colegio, con Pedro a la cabeza, y como colegio recibieron su misión de carácter universal ${ }^{85}$. Sus sucesores, los Obispos, mantienen la mismas estructura colegial, con el Papa a la cabeza, ya que por su ordenación y con la comunión jerárquica son incorporados al colegio episcopal, sucesor del colegio apostólico. Por la ordenación episcopal el nuevo Obispo comienza a formar parte del colegio episcopal y de la misión universal que al mismo le corresponde.

El Obispo actúa siempre como un miembro del colegio episcopal, a condición de que mantenga su comunión jerárquica con el mismo. La misión canónica, por la que un Obispo recibe como oficio propio una parte de la misión de todo el colegio episcopal, no lo aísla del resto del colegio episcopal. Los demás Obispos, todo el colegio episcopal, sigue teniendo parte en la misión que se le ha dado a uno de sus miembros a través de la misión canónica, y éste sigue relacionado con la misión de todo el colegio episcopal.

En este contexto se puede ubicar la insistencia con la que el Papa se refiere a las Conferencias episcopales como expresiones de la colegialidad episcopal. En ellas los Obispos ejercen juntos algunas funciones propiamente

${ }^{83}$ En contramos que es un avance en este intento del estudio de la naturaleza de las Conferencias episcopales desde la teología de la comunión el trabajo de J. Arrieta, Conferenze episcopali e vincolo di comunione, IE 1 (1989) 3-22.

${ }^{84} \mathrm{Cf}$. Concilio Vaticano II, Lumen gentium, $\mathrm{nn}^{\circ} 18-22$.

85 Cf. Mt 28,18-20. 
episcopales, que como tales pertenecen a todo el colegio episcopal. De esta manera las Conferencias episcopales se convierten en expresión de la colegialidad del colegio episcopal. Los elementos propios de la colegialidad episcopal se realizan en las Conferencias episcopales: el ejercicio de un ministerio propiamente episcopal, que es parte, por lo tanto, de la misión del colegio episcopal, a través de la acción conjunta de un grupo de Obispos, en comunión con el colegio episcopal y su cabeza. Es el iunctim, que menciona Juan Pablo II, de un grupo de miembros del colegio episcopal y su cabeza.

De todos modos, ya que ninguna Conferencia episcopal está formada por todos los miembros del colegio episcopal, sino sólo por algunos de ellos, la acción de una Conferencia episcopal no puede ser entendida como una acción del colegio episcopal propiamente dicho. Se debe aceptar, entonces, con Juan Pablo II, que la acción colegial de los Obispos a través de una Conferencia episcopal es una expresión parcial, limitada e incompleta de la colegialidad del colegio episcopal. Pero esto último de ninguna manera quita la naturaleza colegial de la acción conjunta de los Obispos a través de una Conferencia episcopal. La participación que cada Obispos tiene en la misión de todo el colegio episcopal, que es de naturaleza colegial, recibe una verdadera concreción práctica a través de su participación en la Conferencia episcopal, en la que los Obispos ejercen una responsabilidad estrictamente colegial, según el parecer de Juan Pablo II, sobre las Iglesias particulares que la integran.

Dado este origen de las Conferencias episcopales en la naturaleza misma del colegio episcopal, resulta comprensible la frecuencia con la que el Papa menciona los frutos de esta realización práctica de la colegialidad efectiva y afectiva de los Obispos, que redundan en una mayor eficacia de su ministerio.

La realización de la colegialidad, elemento constitutivo del ministerio episcopal, en las Conferencias episcopales, está también indicándonos un camino para la comprensión de la naturaleza eclesiológica de las mismas. La comunión eclesial, que en su realización en el colegio episcopal se expresa en la colegialidad propia y constitutiva del ministerio episcopal y de la comunión jerárquica del colegio, es clave de bóveda para entender la naturaleza eclesiológica de las Conferencias episcopales, y también de su naturaleza canónica ${ }^{86}$.

${ }^{86}$ De todo lo que se ha escrito sobre la colegialidad en relación a las Conferencias episcopales nos interesa citar uno de los últimos trabajos, el de F. Guillemette, Les conférences épiscopales 
The Person and the Challenges
Volume 3 (2013) Number 1

Siempre que se ha entendido la finalidad de las Conferencias episcopales en forma exclusiva o preponderante desde el ejercicio que les corresponde de la potestad legislativa, ha aparecido el temor del cercenamiento, disminución, supresión, sustitución o absorción de la potestad, responsabilidad, competencia, libertad, o autoridad de cada Obispo en su diócesis, con la consiguiente reacción para evitar que se caiga en esos abusos (todos los sinónimos utilizados en esta frase aparecen en los pronunciamientos de Juan Pablo II). Estos temores, además, han impedido profundizar serenamente los fundamentos teológicos de estos coetus episcoporum.

A la luz del pensamiento de Juan Pablo II, estudiado fundamentalmente a través de sus pronunciamientos ante Obispos, teniendo en cuenta el amplio ámbito de la finalidad de las Conferencias episcopales, y en especial, partiendo de la teología de la comunión y profundizando el significado de la colegialidad episcopal, se puede ver cómo la responsabilidad personal propia de cada Obispo respecto de los fieles que se le confían no se opone a la acción en común, el encuentro y el diálogo entre los Obispos para ejercer conjuntamente algunas de sus funciones pastorales, sin que quede cercenada la libertad de cada uno como pastor propio e inmediato de su diócesis.

Desde una profundización de la colegialidad episcopal podría verse que el ministerio de cada Obispo al frente de su Iglesia particular nunca lo aísla de su participación en la misión del colegio episcopal, y que la cercanía con otras Iglesias particulares lo impulsa a asumir conjuntamente con los Obispos que las presiden algunas responsabilidades, dando así una concreción real y visible al lazo sacramental que los une. Y para esto las Conferencias episcopales resultan hoy un instrumento querido por la Iglesia, comenzando por la autoridad suprema de la misma.

La profundización de estos fundamentos de la naturaleza eclesiológica de las Conferencias episcopales ayudó a una mejor y más acabada comprensión y expresión jurídica de las mismas, que el beato Juan Pablo II pudo llevar adelante con el motu proprio Apostolos Suos, pacientemente preparado y anticipado con su magisterio hasta aquí analizado.

sontelles une institution de la collégialité épiscopale?, Studia Canonica 25/I (1991) 3976. El autor avanza con claridad y coherencia desde las enseñanzas del Concilio a la afirmación de la colegialidad existente en las Conferencias episcopales. 


\section{El motu proprio Apostolos Suos}

Ya desde los tiempos del Concilio Vaticano II los teólogos y canonistas trataron de explicarse la intromisión de las Conferencias episcopales en la autoridad de cada Obispo en la propia Iglesia particular, que siempre se consideró de origen divino y sólo sometida a la autoridad del Papa. Mientras algunos trataban de asentar los fundamentos teológicos de esta capacidad jurídica de las Conferencias episcopales, otros los negaban o limitaban.

Las posiciones, con matices que no interesa señalar ahora, podían resumirse en dos. La de los que consideraban a las Conferencias episcopales como organismos pastorales de naturaleza sólo consultiva, que únicamente en casos excepcionales podían ejercer una potestad legislativa delegada expresamente por el Romano Pontífice, y la de los que las trataban como instancias intermedias entre la Santa Sede y el Obispo, pastor de su Iglesia particular, a las que se podía asignar tanta capacidad jurídica como se quisiera ${ }^{87}$.

La relación final de la Asamblea Extraordinaria del Sínodo de los Obispos, convocada por Juan Pablo II a los 20 años de concluido el Concilio para evaluar los frutos de su aplicación, pidió que se investigara más amplia y profundamente el status teológico de las Conferencias episcopales, y sobre todo la cuestión de su autoridad doctrinal. El mismo Juan Pablo II hizo suya esta sugerencia en el discurso de clausura de dicha Asamblea del Sínodo de los Obispos ${ }^{88}$, pero además como hemos visto en el apartado anterior se ocupó vivamente del tema en su magisterio ordinario.

\section{Problemas pendientes}

Los pastores, los teólogos y los canonistas tenían claro en ese momento la utilidad pastoral, incluso la necesidad de contar con las Conferencias episcopales. Estas, constituyendo una aplicación concreta del espíritu colegial, se erigían como instrumentos apropiados para realizar en nuestro tiempo esta dimensión imprescindible del ministerio de los Obispos. Sin embargo, como ya dijimos, no todos entendían del mismo modo los fundamentos teológicos

${ }^{87}$ Un buen resumen de todas las posiciones importantes en este debate se encuentra en Angel Antón, Conferencias episcopales, ¿instancias intermedias?, Sígueme 1989, págs. 176181. El autor se inscribe en la segunda de las posiciones.

${ }^{88}$ Juan Pablo II, Discurso en la clausura de la Asamblea extraordinaria del Sínodo de los Obispos, 7/12/1985, L'Osservatore Romano, Edición semanal en lengua española (1985) 767. 
de las Conferencias episcopales, y como consecuencia llegaban a resultados diversos en los alcances jurídicos que creían conveniente atribuirles.

Tratando de orientar, y al mismo tiempo de dar impulso al estudio de la naturaleza propia de las Conferencias episcopales, Juan Pablo II confió el examen de un posible pronunciamiento sobre el tema a las Congregaciones para los Obispos, para las Iglesias Orientales y para la Evangelización de los Pueblos, con la ayuda de la Secretaría General del Sínodo de los Obispos y la Congregación para la Doctrina de la Fe.

El fruto del estudio de estos organismos vio la luz el $1^{\circ}$ de julio de 1987 con la forma de un Instrumentum laboris, que pretendía dar algunas orientaciones sobre el status teológico y jurídico de las Conferencias episcopales ${ }^{89}$. Enviado a las Conferencias episcopales de todo el mundo, fue duramente criticado, como recordaba el Secretario de la Congregación para los Obispos ${ }^{90}$. Esto dio lugar a otro proyecto totalmente nuevo, que fue la base del último motu proprio de Juan Pablo II, Apostolos Suos, sobre la naturaleza teológica y jurídica de las Conferencias episcopales, promulgado el 21 de mayo de 1998. Este pronunciamiento constituye así la última etapa de un largo camino comenzado hace 13 años en la Asamblea Extraordinaria del Sínodo de los Obispos de 1985.

Es clara la diferente naturaleza de estos dos documentos. En el primer caso, el Instrumentum laboris, estamos ante un elemento de trabajo, preparado por un dicasterio romano, para ser sometido al parecer de todos los Obispos, con el fin de preparar el terreno para una intervención posterior de la autoridad suprema. El segundo caso, en cambio, el motu proprio Apostolos Suos, constituye un claro ejercicio de la potestad magisterial y legislativa del Papa, introduciendo algunas normas complementarias a las que el Código brindaba sobre las Conferencias episcopales y haciendo algunas aclaraciones de carácter doctrinal y jurídico que, sin pretender cerrar la puerta a ulteriores profundizaciones, hacen concisas precisiones sobre la naturaleza teológica y jurídica de estas Conferencias ${ }^{91}$.

${ }^{89}$ Este Instrumentum laboris fue publicado en Enchiridion Vaticanum (EV) 10 (1987) 1286-1305 y en la Revista Il Regno. Documenti, 33 (1988) 390396. Nosotros utilizaremos la primera publicación.

${ }^{90}$ Cf. F. Monterisi, Intervento del Segretario della Congregazione per i Vescovi, en L'Osservatore Romano del 24 luglio 1998, pág. 7.

${ }_{91}$ Cf. J. I. Arrieta, Le conferenze episcopali nel motu proprio Apostolos Suos, Ius Ecclesiae XI (1999) 169-191 y J. R. Villar, La naturaleza de las Conferencias episcopales y la Carta Apostolos Suos, Scripta theologica XXXI (1999) 115-137. 
Sin embargo, con la finalidad de llegar a una mejor comprensión del motu proprio, nos ha parecido que valía la pena partir del famoso y en su momento discutido Instrumentum laboris, para poner en evidencia aquellas cosas en las que creemos se ha dado un real avance, no sólo en la clarificación doctrinal sino también en la legislación universal sobre las Conferencias episcopales, así como también para señalar algunos puntos en los que todavía es de esperar un mayor progreso.

Resumiremos en primer lugar el contenido del Instrumentum laboris, para abordar después el motu proprio Apostolos Suos, para poder sacar algunas conclusiones a la luz de los cambios producidos entre uno y otro.

\section{El Instrumentum laboris}

Este trabajo pretendía ser competo, aunque no definitivo, al presentar el estatuto teológico y jurídico de las Conferencias episcopales. Las preguntas añadidas al final del Instrumentum laboris ponen de manifiesto la pretensión de abrir la discusión a nuevos aportes ${ }^{92}$.

\subsection{Estatuto teológico de las Conferencias episcopales}

Comenzaba estableciendo los fundamentos teológicos de las Conferencias episcopales a partir de la Iglesia entendida como communio y la colegialidad episcopal, como manifestación de la communio entre los Pastores ${ }^{93}$. Con esta base, pone de manifiesto las actuaciones de la colegialidad episcopal, que encuentran su fundamento en el origen sacramental del Colegio episcopal, y que son de dos tipos: los actos colegiales en sentido estricto, propios de todo el Colegio episcopal, y los actos colegiales en sentido teológicamente impropio, o de colegialidad analógica, cuando se trata de una acción de sólo una parte de los miembros del Colegio episcopal ${ }^{94}$.

A continuación el Instrumentum laboris afirmaba la naturaleza a la vez colegial y personal de la función episcopal, por la que todo acto episcopal debe considerarse al menos de una manera implícita como colegial, en la medida en que el Obispo se encuentre en comunión con todo el Colegio, del que siempre es parte ${ }^{95}$.

\footnotetext{
${ }^{92}$ Cf. Instrumentum laboris, Introduzione, EV 10 (1987) 1288.

${ }_{93}$ Cf. Instrumentum laboris, Status teologico delle Conferenze episcopali, I, EV 10 (1987) $1288-1290$.

${ }^{94}$ Cf. Instrumentum laboris, Status teologico delle Conferenze episcopali, II, EV 10 (1987) $1290-1292$.

${ }^{5}$ Cf. Instrumentum laboris, Status teologico delle Conferenze episcopali, III, EV 10 (1987) $1293-1295$.
} 
The Person and the Challenges
Volume 3 (2013) Number 1

A partir de aquí el Instrumentum laboris hacía una serie de deducciones que debían aplicarse a las Conferencias episcopales. Ubicaba sus fundamentos remotos en la solicitud de cada Obispo por la Iglesia universal, y ponía como ejemplo los Concilios particulares realizados a lo largo de la historia. Los fundamentos próximos los consideraba de orden más práctico y pastoral, y esto explicaba las diferencias entre los Concilios particulares y las Conferencias episcopales, y las mayores atribuciones de potestad que tienen aquellos. Considera que las Conferencias episcopales son expresiones sólo en sentido analógico de la colegialidad episcopal, que han sido instituidas no para gobernar pastoralmente una nación ni para sustituir a los Obispos por una gobierno de carácter superior, sino para ayudarlos en las tareas comunes que les presenta su ministerio, de modo tal que las decisiones de las Conferencias episcopales emanan de la autoridad de los Obispos que las componen, que ejercen conjuntamente la potestad que cada uno de ellos han recibido en la consagración episcopal, para ejercer en su propia diócesis ${ }^{96}$.

El Instrumentum laboris concluía esta presentación del estatuto teológico de las Conferencias episcopales afirmando que éstas en cuanto tales no gozan de un munus magisterial, y no tienen, por lo tanto, competencia para establecer contendidos dogmáticos a través de sus declaraciones, razón por la que ${ }^{97}$.

\subsection{El status jurídico de las Conferencias episcopales}

En cuanto al poder legislativo de las Conferencias episcopales, el Instrumentum laboris consideraba que se trataba de una potestad ordinaria en las materias previstas por la legislación universal de la Iglesia, y de una potestad delegada en aquellas otras que les fueran atribuidas por "especial mandato". Les reconoce la función pastoral que el Concilio y el Código afirman al señalar que los Obispos ejercen conjuntamente en las Conferencias episcopales algunas funciones pastorales ${ }^{98}$. Y su capacidad magisterial la limita a la posibilidad de hacer una aplicación del magisterio universal de

${ }^{96}$ Cf. Instrumentum laboris, Status teologico delle Conferenze episcopali, IV, EV 10 (1987) $1295-1299$.

${ }^{97}$ Cf. Instrumentum laboris, Status teologico delle Conferenze episcopali, V, EV 10 (1987) 1299-1301.

${ }^{98}$ Cf. ibid. Sobre la diferencia de los términos utilizados por el Concilio (munus suum pastorale) y el Código (munera quaedam pastoralia), cf. A. Bunge, Precisiones jurídicas sobre las funciones de las Conferencias episcopales. Aportes del magisterio de Juan Pablo II, Buenos Aires, EDUCA 1996, págs. 427-429. 
la Iglesia a las propias circunstancias, con el voto de más de dos tercios de sus miembros, y contando con la recognitio de la Santa Sede, invitándolas a dejar para los eventuales Concilios plenarios el tratamiento de las cuestiones doctrinales más relevantes ${ }^{99}$.

Analizando la relación de cada Obispo con la Conferencia episcopal de la que forma parte, el Instrumentum laboris reconoce que las decisiones vinculantes que ésta puede tomar deben entenderse como una limitación de la potestad del Obispo en su diócesis, realizada en virtud de la potestad de la Cabeza del Colegio episcopal, y que en los demás casos hay que reconocer que permanece intacta la libertad de cada Obispo, aunque en virtud de la autoridad moral de las decisiones de la Conferencia episcopal en materias no vinculantes, se lo exhorta a no disentir si no es por graves razones pesadas delante de Dios ${ }^{100}$.

Finalmente, afirmando que la Asamblea plenaria de la Conferencia episcopal es su órgano constitutivo, que en último análisis se identifica con ella, el Instrumentum laboris advierte la necesidad de no confundir los organismos subalternos con las comisiones episcopales y con la misma Conferencia, y a contar con una mayoría cualificada a la hora de tomar decisiones no vinculantes en el seno de la Asamblea plenaria de la Conferencia episcopal ${ }^{101}$.

\section{El motu proprio Apostolos Suos}

Esta Carta Apostólica del beato Juan Pablo II es fruto de un intenso trabajo llevado adelante por su incesante magisterio sobre la materia, como ya hemos visto, y del trabajo de los estudiosos en los que el Papa supo encontrar la luz que lo llevó a tomar precisas determinaciones.

\subsection{Introducción}

Juan Pablo II comienza este motu proprio aludiendo, con abundantes citas evangélicas y del Concilio Vaticano II, a los fundamentos de la misión apostólica y su continuación hasta el fin de los tiempos en la misión episcopal, que tiene desde su origen un carácter colegial. Recuerda que siempre se ha

${ }^{99}$ Instrumentum laboris, Status giuridico delle Conferenze episcopali, I, EV 10 (1987) 1301-1302.

${ }^{100}$ Instrumentum laboris, Status giuridico delle Conferenze episcopali, II, EV 10 (1987) 13021303. Cf. Congregación para los Obispos, Directorio Ecclesiae imago, n. 212.

${ }^{101}$ Instrumentum laboris, Status giuridico delle Conferenze episcopali, III, EV 10 (1987) 13031304. 
mantenido viva en la Iglesia la conciencia de la potestad que, por institución divina, tiene el Obispo en su Iglesia particular, junto con la conciencia de que todos los Obispos forman parte de un único cuerpo, que se ha expresado utilizando diversos instrumentos de comunicación para poner de manifiesto la comunión y la preocupación por todas las Iglesias ${ }^{102}$.

En este contexto Juan Pablo II inscribe la aparición de las Conferencias episcopales el siglo pasado (llamadas con este nombre por la Santa Sede a partir del año 1889), con el objeto de afrontar las cuestiones eclesiales de interés común, para dar las oportunas soluciones. El Papa resalta la importancia que las Conferencias episcopales han ido adquiriendo con el tiempo, porque contribuyen eficazmente a la unidad entre los Obispos, y como consecuencia a la unidad de la Iglesia, y que por esta razón han sido elegidas por los Obispos como el órgano preferido para el intercambio, la consulta y la mutua colaboración, sobre todo a partir del Concilio Vaticano II. No deja de percibir, sin embargo, los problemas que surgen, especialmente en la relación de las Conferencias episcopales con cada uno de los Obispos diocesanos. A partir de allí pretende explicitar los principios teológicos y jurídicos básicos de las Conferencias episcopales, y complementar las normas jurídicas que actualmente las regulan, para que sea posible una praxis teológicamente fundada y jurídicamente segura ${ }^{103}$.

\subsection{Unión colegial entre los Obispos}

La unión colegial de los Obispos, afirma Juan Pablo II, manifiesta la naturaleza misma de la Iglesia. El misterio de la comunión eclesial que impregna toda la Iglesia, configura también al Colegio episcopal. Los Obispos, colegialmente unidos, son sujeto de la potestad suprema de la Iglesia, nos recuerda el Papa con palabras del Concilio Vaticano II, y el Sumo Pontífice tiene esa misma potestad, que puede ejercer siempre con entera libertad. Los Obispos sólo pueden ejercer colegialmente esta autoridad suprema sobre toda la Iglesia, y siempre convocados, o al menos con la aprobación o aceptación del Papa de una acción conjunta. En cambio, en el ámbito de las Iglesias particulares o de sus agrupaciones, por ejemplo en las Conferencias episcopales, los Obispos no ejercen esta autoridad suprema, y su actividad es estrictamente personal, no colegial, aunque esté siempre animada por el espíritu de la comunión ${ }^{104}$.

\footnotetext{
${ }^{102}$ Cf. Apostolos Suos, I. Introducción, nros. 1-3.

${ }^{103}$ Cf. ibid., nros. 4-7.

${ }^{104}$ Cf. Apostolos Suos, II. Unión colegial entre los Obispos, nros. 8-10.
} 
La pertenencia de los Obispos al Colegio episcopal se pone de manifiesto no sólo en los actos estrictamente colegiales, sigue Juan Pablo II, sino también en la solicitud de cada Obispo por toda la Iglesia. De esta manera, los Obispos siempre actúan como miembros del Colegio episcopal, cuando ejercen su ministerio de enseñanza, santificación y conducción. Por eso, aunque cuando realizan estos ministerios en su Iglesia particular, o conjuntamente sobre un grupo de ellas, no se dirigen a todos los fieles, su acción redunda en el crecimiento y el bien de toda la Iglesia ${ }^{105}$.

Cuando los Obispos, continúa el Papa, ejercen conjuntamente algunas funciones pastorales para el bien de sus fieles (por ejemplo en las Conferencias episcopales), hacen una aplicación concreta del espíritu colegial de su ministerio (el affectus collegialis), pero no realizan un acto propiamente colegial, que sólo es propio de la totalidad de los Obispos como sujeto de la autoridad suprema de la Iglesia. Así como la Iglesia universal es una realidad ontológica y temporalmente previa a cada Iglesia particular ${ }^{106}$, el Colegio episcopal es una realidad previa al oficio de los Obispos de presidir las Iglesias particulares, y además es, como sujeto teológico, indivisible. La relación de „mutua interioridad" de la Iglesia universal y las Iglesias particulares (Ecclesia in et ex Ecclesiis, afirma el Concilio, Ecclesiae in et ex Ecclesia, agrega Juan Pablo II $)^{107}$, no se repite en la relación de las Conferencias episcopales con las respectivas Iglesias particulares. La relación de las Conferencias episcopales con los Obispos que las integran es análoga, pero no igual a la relación del Colegio episcopal con dichos Obispos ${ }^{108}$.

\subsection{Las Conferencias episcopales}

En el motu proprio se recogen todas las normas vigentes sobre las Conferencias episcopales junto con sus fundamentos en el Concilio, y se agregan algunas precisiones sobre los principios jurídicos que las iluminan ${ }^{109}$.

La eficacia vinculante de los actos de los Obispos ejercidos conjuntamente en las Conferencias episcopales, afirma Juan Pablo II, proviene de que

${ }^{105}$ Cf. ibid., n. 11.

${ }^{106} \mathrm{Cf}$. Congregación para la Doctrina de la Fe, Instrucción Communionis notio, n. 9.

${ }^{107}$ Cf. Lumen gentium, nro. 23 y Juan Pablo II, Discurso a la Curia Romana, 20/12/1990, n. 9, L'Osservatore Romano, Edición semanal en lengua española (1990) 750.

${ }^{108}$ Cf. Apostolos Suos, II. Unión colegial entre los Obispos, nros. 12-13.

${ }^{109}$ Cf. cáns. 447455; cf. Apostolos Suos, III. Las Conferencias episcopales, n. 14. 
la Sede Apostólica las ha constituido y les ha confiado algunas tareas determinadas ${ }^{110}$.

El Papa señala algunos de los campos donde hoy es necesario una acción conjunta de los Obispos, que se realiza a través de las Conferencias episcopales: la promoción y la tutela de la fe y las costumbres, la traducción de los libros litúrgicos, la promoción y la formación de las vocaciones sacerdotales, la elaboración de los materiales de catequesis, la formación y la tutela de las universidades católicas y otras instituciones educativas, el compromiso ecuménico, las relaciones con las autoridades civiles, la defensa de la vida humana, de la paz y de los derechos humanos, la promoción de la justicia social, etc. ${ }^{111}$.

Partiendo de la potestad propia, ordinaria e inmediata que tiene cada Obispo en su Iglesia particular, que ejerce en nombre de Cristo, el Papa aclara que su ejercicio está regulado por la autoridad suprema, que puede circunscribirlo dentro de ciertos límites, con vistas al bien común, como se hace con las competencias que se confían a las Conferencias episcopales. En este caso, los Obispos ejercen su ministerio episcopal en aquellas materias que les ha confiado la autoridad suprema de un modo que resulta obligatorio para todos ellos y sus respectivas Iglesias ${ }^{112}$.

El ejercicio conjunto del ministerio episcopal incluye también la función doctrinal. Mientras la legislación universal es clara y precisa al señalar las ocasiones en las que las Conferencias episcopales pueden tomar decisiones vinculantes, y el modo y las condiciones para llegar a esas decisiones, con un claro criterio limitativo, no era hasta el momento igualmente precisa sobre las ocasiones y el modo en que los Obispos podían ejercer unidos en las Conferencias episcopales su autoridad doctrinal, produciendo un magisterio auténtico, al que los fieles deben adherirse con un asentimiento religioso ${ }^{113}$.

Aclarando que los pronunciamientos de las Conferencias episcopales no son necesariamente magisterio universal de la Iglesia (si no lo enseñan todos los demás Obispos en las condiciones requeridas para ser considerado magisterio universal), el Papa exhorta a los Obispos a evitar con cuidado dificultar la labor doctrinal de los Obispos de otros territorios, dada la

\footnotetext{
${ }^{110}$ Cf. Apostolos Suos, II. Unión colegial entre los Obispos, n. 13.

${ }^{111}$ Cf. Apostolos Suos, III. Las Conferencias episcopales, n. 15.

${ }^{112}$ Cf. Apostolos Suos, III. Las Conferencias episcopales, nros. 19-20.

${ }^{113} C f$. can. 753 .
} 
resonancia que los actuales medios de comunicación social dan en todo el mundo a los acontecimientos de una determinada región ${ }^{114}$.

Pero al mismo tiempo fija con toda precisión las ocasiones y el modo en que éstas pueden ejercer un magisterio auténtico, al que los respectivos fieles deben adherirse con religioso asentimiento. En primer lugar, debe tratarse de una enseñanza que está en comunión con el Papa y con el Colegio episcopal. Supuesto esto, si las declaraciones doctrinales de las Conferencias episcopales son aprobadas por unanimidad, pueden ser publicadas sin más requisitos en nombre de la Conferencia, y todos los fieles deben adherirse con religioso asentimiento. $\mathrm{Si}$, en cambio, falta dicha unanimidad, para que la declaración doctrinal pueda ser publicada como magisterio auténtico y en nombre de la Conferencia episcopal, hace falta que sea aprobada en Asamblea Plenaria al menos por los dos tercios de los Prelados que pertenecen a la Conferencia con voto deliberativo, y que se obtenga el reconocimiento (recognitio) de la Sede Apostólica. Por otra parte, ningún organismo de las Conferencias episcopales, fuera de la Asamblea Plenaria, puede realizar actos de magisterio auténtico ${ }^{115}$.

De esta manera, el Papa ha puesto fin a las discusiones sobre el valor doctrinal de las declaraciones y pronunciamientos de las Conferencias episcopales, no suficientemente aclarado por las determinaciones del Código de Derecho Canónico.

\subsection{Normas complementarias sobre las Conferencias episcopales}

Finalmente el Papa, después de la introducción y las aclaraciones de carácter doctrinal y canónico que hemos expuesto, concluye el motu proprio con las normas complementarias, que a partir de ahora deben agregarse a las determinaciones del Código de Derecho Canónico, para tener el conjunto de las decisiones canónicas universales sobre las Conferencias episcopales.

Resumidamente estas normas determinan que, para que las declaraciones doctrinales de una Conferencia episcopal constituyan magisterio auténtico y pueda ser publicada en nombre de la misma Conferencia, debe contar con la aprobación unánime de los miembros de la misma, o la aprobación de los dos tercios de los miembros dada en reunión plenaria, pero en este segundo

\footnotetext{
${ }^{114}$ Cf. Apostolos Suos, III. Las Conferencias episcopales, n. 21.

${ }^{115}$ Cf. Apostolos Suos, III. Las Conferencias episcopales, nros. 22-24.
} 
caso contando con la recognitio dada por la Santa Sede ${ }^{116}$. Esta capacidad de realizar magisterio auténtico sólo pertenece a la reunión plenaria de la Conferencia episcopal, y no es delegable a ningún otro organismo o parte de la misma ${ }^{117}$. Para otro tipo de intervenciones doctrinales, que no llegan a constituir magisterio auténtico, la comisión doctrinal de la Conferencia episcopal necesita una delegación explícita dada por la comisión permanente ${ }^{118}$. Finalmente, las Conferencias episcopales deberán revisar sus estatutos para que sean coherentes con estas aclaraciones y normas del motu proprio Apostolos Suos, y enviarlos a la Santa Sede para la correspondiente recognitio ${ }^{119}$.

\section{Apostolos Suos a la luz del Instrumentum laboris}

Resulta de utilidad analizar el motu porpio a la luz del Instrumentum laboris recién mencionado, para encontrar la solución que el Papa aporta a los problemas planteados.

\subsection{Colegialidad y comunión}

Si comparamos el motu proprio de Juan Pablo II Apostolos Suos con su antecedente remoto, el Instrumentum laboris, nos encontramos en primer lugar con que ya no se presentan el misterio de la communio ecclesialis y la colegialidad episcopal como los fundamentos teológicos de las Conferencias episcopales con la misma fuerza con que lo hacía el primer proyecto.

Aunque se sigue teniendo en cuenta que los Obispos siempre actúan como miembros del Colegio episcopal, se evita cuidadosamente aplicar el adjetivo "colegial" a cualquier acción de varios Obispos en bien de sus respectivas Iglesias. Ni siquiera se permite el motu proprio llamar a estos actos colegiales en sentido impropio o de colegialidad analógica, considerándolos sólo manifestaciones del espíritu colegial o affectus collegialis, que es propio de toda acción episcopal. Se hecha de menos la consideración que hacía el Instrumentum laboris de la función episcopal como colegial por naturaleza, en virtud de lo cual todos los actos de un Obispo, aunque en cuanto tales son siempre personales, deban ser entendidos abiertos a una colegialidad al menos implícita.

\footnotetext{
${ }^{116}$ Cf. Apostolos Suos, IV. Normas complementarias sobre las Conferencias episcopales, art. 1.

${ }^{117}$ Cf. ibid., art. 2.

${ }^{118}$ Cf. ibid., art. 3.

${ }^{119}$ Cf. ibid., art. 4.
} 
Debemos entender que se tiene este cuidado porque se quiere estar especialmente atentos a la necesidad de impedir que la acción de las Conferencias episcopales pueda verse como una interferencia indebida en la potestad y la misión de cada Obispo al frente de su Iglesia particular, que se considera de origen divino.

Creo, sin embargo, que se realiza una excesiva separación entre el carácter colegial de las acciones de todo el Colegio episcopal y la naturaleza estrictamente personal de la actividad del Obispo al frente de su Iglesia particular, con el riesgo de no tener en cuenta que el Obispo está actuando siempre como miembro del único Colegio episcopal, continuación en el tiempo del Colegio apostólico, que recibió como Colegio la única misión confiada por Cristo a toda la Iglesia ${ }^{120}$.

Tomando este punto de partida, la única misión confiada por Jesucristo al único Colegio apostólico, hoy continuado en el Colegio episcopal, me parece más adecuado considerar que la potestad de cada Obispo, más que "estrictamente personal", es una potestad "del Colegio episcopal", en la que cada Obispo participa por la ordenación episcopal y por la comunión con el mismo Colegio, y que ejerce "en un lugar", su Iglesia particular, que el mismo Colegio, a través de su Cabeza, le ha asignado ${ }^{121}$.

\subsection{Decisiones vinculantes de las Conferencias episcopales}

Encontramos en cambio un gran avance desde el Instrumentum laboris hasta el motu proprio Apostolos Suos en la claridad con la que se atribuye la eficacia vinculante de las decisiones de la Conferencia episcopal a su erección por parte de la Santa Sede y a la delegación que éste le hace de determinadas materias.

La capacidad de tomar decisiones vinculantes para todos sus miembros, por encima de la autoridad de cada Obispo considerado singularmente, ha sido un punto convergente, y para algunos exclusivo, del debate sobre la naturaleza teológica y jurídica de las Conferencias episcopales. La doctrina ya avanzó suficientemente sobre esta materia, dejando en claro que no se puede negar esta capacidad jurídica de las Conferencias episcopales. Pero no todos los autores habían coincidido al individualizar sus fundamentos.

\footnotetext{
${ }^{120} \mathrm{Cf}$. Mt 28, 18-20.

${ }^{121} \mathrm{Cf}$. Concilio Vaticano, Lumen gentium, n. 21b.
} 
Ahora Juan Pablo II ha dicho una palabra clara y magisterial sobre el asunto. Y para eso parte de la autoridad del Romano Pontífice y del Colegio episcopal, afirmando que son elementos propios de la Iglesia universal, e integran cada Iglesia particular. Partiendo de allí, el Papa pone el fundamento de la limitación de la potestad propia, ordinaria e inmediata de cada Obispo en su Iglesia particular a través de las decisiones vinculantes de la Conferencia episcopal, en la potestad del Romano Pontífice, que puede intervenir en la jurisdicción episcopal, reservando determinadas causas para sí o para otros ${ }^{122}$.

De todos modos, cabría preguntarse si esta misma argumentación dada para fundamentar la potestad de tomar decisiones vinculantes que tienen las Conferencias episcopales, debe aplicarse a otras reuniones de Obispos, como los Concilios particulares.

Si así fuera, creo que sería muy difícil explicar cómo se concedía esta potestad a los Concilios particulares de los primeros siglos de la Iglesia, que fueron muchos y muy importantes, en tiempos en que no existía un ejercicio efectivo del primado de Pedro como hoy conocemos, sino que incluso su Sucesor no se enteraba de algunos de dichos Concilios hasta después de mucho tiempo de celebrados y aplicados.

Y si así no fuera, cabría preguntarse si otros fundamentos que se han dado para el ejercicio de una potestad con las que los Concilios particulares tomaban decisiones vinculantes desde los primeros tiempos de la Iglesia, no fuesen también aplicables a las Conferencias episcopales, resultando incluso más completos y acabados que los que hoy brinda Apostolos Suos. Creo que en esta materia no está todavía cerrado el campo de la investigación, como el mismo Cardenal Prefecto de la Congregación para la Doctrina de la Fe aclaraba en su discurso el día de la presentación del motu proprio ${ }^{123}$.

\subsection{Autoridad magisterial de las Conferencias episcopales}

Creo finalmente que es determinante, y el fruto más claro que ha aportado Apostolos Suos, al menos desde el punto de vista legislativo, el esclarecimiento de la capacidad magisterial de las Conferencias episcopales. Durante mucho

${ }^{122}$ En este caso para la respectiva Conferencia episcopal; $c f$. can. $381 \S 1$.

${ }^{123}$ J. Ratzinger, Intervento del Prefetto della Congregazione per la Dottrina della Fede, en L'Osservatore Romano del 24 luglio 1998, pág. 1. 
tiempo debatieron los autores sobre este asunto, con posiciones decididamente encontradas ${ }^{124}$.

Ahora el Papa ha zanjado la discusión canónica, afirmando sin lugar a dudas la autoridad magisterial de las Conferencias episcopales que, en precisas circunstancias y con los modos determinados en las nuevas normas, pueden ser propiamente sujetos de un magisterio auténtico, al que los fieles deben prestar religioso obsequio ${ }^{125}$. Esto supone un claro avance sobre el Instrumentum laboris, que afirmaba que las Conferencias episcopales, en cuanto tales, no gozaban de un munus magisterii, y no constituían una instancia doctrinal, razón por la que no tenían competencia para establecer contenidos dogmáticos y morales ${ }^{126}$.

\section{Conclusiones sobre Apostolos Suos}

Si tenemos en cuenta la clarificación de los fundamentos teológicos de las Conferencias episcopales, podemos decir que el Instrumentum laboris presentado por la Congregación para los Obispos en el año 1987 era más amplio y más explícito que el motu proprio que estamos comentando. Un autor inclinado a entender las Conferencias episcopales como instancias intermedias entre la autoridad suprema del Papa y el Colegio episcopal por una lado, y el Obispo diocesano por el otro, se ha ocupado en un reciente artículo de tratar de demostrar que Apostolos Suos ha dejado perfectamente en pie sus afirmaciones, y en los puntos en los que no coincide con ellas el campo ha quedado abierto a la investigación tanto teológica como canónica ${ }^{127}$. Sin embargo, creo que el motu proprio ha puesto los carriles de la interpretación dentro de cauces más estrechos de los que se requieren para entender a las Conferencias episcopales como instancias intermedias entre la autoridad suprema y la autoridad del Obispo diocesano ${ }^{128}$.

\footnotetext{
${ }^{124}$ Es conocido el debate público tenido por dos colegas de la Pontificia Universidad Gregoriana sobre el tema, publicado primero en Periodica y posteriormente como separata: G. Ghiralda y F. Urrutia, Conferentiae Episcoporum et Munus docendi, Romae 1987. Otros autores también se han ocupado profusamente del tema; quiero señalar especialmente a J. Manzanares, La autoridad doctrinal de las Conferencias episcopales, en Naturaleza y futuro de las Conferencias episcopales. Actos del Coloquio internacional de Salamanca, 3-8 de enero de 1988, Salamanca 1988, págs. 289-321.

${ }^{125} \mathrm{Cf}$. artículo de Pedro Daniel Martínez en este mismo número del AADC.

${ }^{126} \mathrm{Cf}$. Instrumentum laboris, Status teologico delle Conferenze episcopali, V, EV 10 (1987) $1300-1301$.

${ }^{127}$ Cf. A. Antón, Gregorianum 80 (1999) 263-297.

${ }^{128}$ Cf. A. Antón, Conferencias episcopales, ¿instancias intermedias?, Salamanca 1989, 495 págs.
} 
Por otra parte, la clarificación doctrinal sobre la relación de la potestad de las Conferencias episcopales de tomar decisiones vinculantes para todos sus miembros con la potestad primacial ha tomado posición en la discusión doctrinal de los últimos años, centrado en la naturaleza de la potestad de las Conferencias episcopales. Es cierto que, como hemos dicho, no está cerrado el debate sobre este punto, pero tampoco será fácil, como no lo fue hasta ahora, seguir avanzando sobre el mismo.

Creo que es de una gran utilidad que Apostolos Suos nos haya brindado un complemento normativo, que a partir de ahora deberá tenerse en cuenta junto con los cánones dedicados en el Código a las Conferencias episcopales, sobre capacidad de realizar magisterio auténtico ${ }^{129}$. Esto no sólo ha puesto punto final a una discusión canónica, dejando completamente en claro la autoridad doctrinal que corresponde a las Conferencias episcopales, dentro de límites perfectamente precisados tanto en las normas como en los fundamentos teológicos y jurídicos de las mismas, sino que además obliga a las Conferencias episcopales a revisar su práctica en la elaboración de pronunciamientos doctrinales, y sus estatutos, para conformarlos a las nuevas normas.

El motu proprio promulgado por Juan Pablo II el 21 de mayo de 1998 ha afrontado la enorme cantidad de críticas que recibió el Instrumentum laboris presentado el $1^{\circ}$ de julio de 1987, avanzando con prudencia algunos pasos, conforme al pedido de la Asamblea Extraordinaria del Sínodo de los Obispos del año 1985, de investigar más amplia y profundamente el status teológico de las Conferencias episcopales, sobre todo la cuestión de su autoridad doctrinal. No está todo dicho, y algunos límites puestos por los fundamentos teológicos que afirma Apostolos Suos pueden resultar estrechos para los que hasta el momento han sostenido las posiciones más avanzadas.

Es cierto que el motu proprio del Papa es sobrio y a la vez preciso en las afirmaciones doctrinales, fijando los cauces de la investigación. No avanza más allá de lo que ha quedado claro en el debate teológico y canónico realizado hasta el momento, y al mismo tiempo cierra las puertas a las afirmaciones más aventuradas, tanto de los que pretendían encerrar a las Conferencias episcopales en tareas de naturaleza sólo consultiva, como de aquellos que pretendían justificar autónomamente su capacidad jurídica. Sin embargo, creo que estos últimos han perdido más terreno.

${ }^{129} \mathrm{Es}$ de auspiciar que en las nuevas ediciones del Código se incluyan siempre los cuatro artículos de las Normas complementarias del motu proprio Apostolos Suos junto a los cánones 447-459, dedicados a las Conferencias episcopales. 
Debe recordarse finalmente la importancia de las Conferencias episcopales en la vida de la Iglesia va mucho más allá de las decisiones vinculantes que a veces toman, a norma del derecho (sin que por esto deba pensarse que las decisiones vinculantes no tengan su propia eficacia y provecho), e incluso más allá del magisterio auténtico que puedan pronunciar en algunas oportunidades.

En efecto, la mayor parte de la labor de las Conferencias episcopales se desarrolla en ese amplio campo en el que los Obispos realizan conjuntamente pronunciamientos, o adoptan del mismo modo actitudes, planes, posiciones o decisiones pastorales, sin que las mismas tengan una fuerza jurídica vinculante. $\mathrm{Y}$ esto lo hacen en el ejercicio de los tria munera, docendi, sanctificandietregendi, del ministerio episcopal.

Ya nos decía el Concilio que existen hoy muchos campos de la acción pastoral, en los que los Obispos no pueden cumplir debida y fructuosamente su cargo, si no se unen estrechamente con otros Obispos, para trabajar de una manera concorde ${ }^{130}$.

Los Obispos están llamados, ante los problemas pastorales que hoy enfrentan, y en orden a su eficacia evangélica, por razón de la naturaleza misma de su ministerio y por el Concilio, tal como vimos en el párrafo anterior, a actuar conjuntamente. Para lo cual deben superar las diversas líneas o visiones personales a través de la consensio episcoporum, que se construye, también más allá del estrecho ámbito de las decisiones vinculantes, en las Conferencias episcopales.

Esto se aplica a todos los asuntos pastorales que los Obispos, en el momento actual, no pueden afrontar eficazmente en forma aislada, y que, por lo tanto, requieren ser asumidos viribus unitis, en orden a un más fructuoso desempeño de la función episcopal ${ }^{131}$.

Que las Conferencias episcopales hayan alcanzado en el Concilio Vaticano II su actual estatuto jurídico, con la capacidad de tomar decisiones con fuerza vinculante en varios ámbitos de la pastoral, no nos debe hacer perder de vista que por su fisonomía inicial son instituciones de carácter predominantemente consultivo, a través de las cuales los Obispos enfrentan coniunctim amplios campos de su acción pastoral, prácticamente todos los que presentan problemas

${ }^{130}$ Cf. Christus Dominus, $\mathrm{n}^{\circ} 37$.

${ }^{131}$ Cf. Juan Pablo II, Discurso a los Obispos de Campania, Italia, con ocasión de su visita ad limina, 21/11/1981, AAS 74 (1982) 4953, pág. 52. 
pastorales que superan la dimensión de la Iglesia particular, yendo mucho más allá del estricto ámbito de las decisiones vinculantes ${ }^{132}$.

El Código no supone una interrupción en esta evolución de las Conferencias episcopales, que respeta su fisonomía inicial (instrumentos de la consensio episcoporum), ni un cambio de dirección. La Pontificia Comisión para la Revisión del Código en su Relación del 16 de julio de 1981, sostenía que las Conferencias episcopales debían conservar el carácter que para ellas quiso el Concilio, no como órganos prevalentemente legislativos y centralizadores, sino como órganos de unión y comunicación entre los Obispos ${ }^{133}$. Tampoco lo supone el motu proprio Apostolos Suos.

\section{Exhortación apostólica postsinodal Pastores Gregis}

Esta Exhortación apostólica de Juan Pablo II, del 16 de octubre de 2003 recoge las proposiciones hechas por la $\mathrm{X}$ Asamblea general ordinaria del Sínodo de los Obispos, que trató del Obispo, servidor del Evangelio de Jesucristo para la esperanza del mundo. Tiene un carácter claramente magisterial y doctrinal.

También éste es un pronunciamiento doctrinal autoritativo del Pastor supremo. Pero en este caso hay que tener en cuenta además que recoge el fruto de la reflexión realizada en una Asamblea general ordinaria del Sínodo de los Obispos, expresión del Colegio episcopal ${ }^{134}$.

El Obispo, afirma Juan Pablo II en Pastores gregis, nunca está solo, ya que siempre actúa como miembro del Colegio episcopal y en comunión con el Colegio y su Cabeza. Pero además, el afecto colegial se realiza y se expresa en diferentes grados y de diversas maneras, incluso institucionalizadas, como sucede en el caso del Sínodo de los Obispos, de los Concilios particulares y de

\footnotetext{
${ }^{132}$ Cf. G. Feliciani, Le Conferenze episcopali..., págs. 529-530.

133 "Hoc factum est post consultationem, quia permulti id petierunt, quo magis extollatur auctoritas et potestas Episcopi dioecesani in propria Ecclesia particulari. Et merito quidem, quia Conferentia Episcoporum non intellegitur primarie ut coetus legislativus qui fere omnia centralizare debeat, sed est praesertim organum unionis et communicationis Episcoporum inter se, ita ut in regimine propriae dioecesis, unusquisque procedere valeat 'communicatis prudentiae et experientiae luminibus collatisque consiliis' (Decr. Christus Dominus, n. 37), et propterea in eodem Decreto conciliari statuitur decisiones Conferentiae vim iuridice obligandi habere dumtaxat in casibus expresse definitis (n. 38, 4)", Communicationes 14 (1982) 199.
}

${ }^{134} \mathrm{Cf}$. Juan Pablo II, Exhortación Apostólica Pastores gregis, n. 58. 
las Conferencias episcopales. De todos modos, el Colegio episcopal se realiza y manifiesta de manera plena sólo en la actuación colegial en sentido estricto, es decir, en la actuación de todo el Colegio episcopal junto con su Cabeza, ejerciendo la potestad plena y suprema sobre toda la Iglesia ${ }^{135}$.

El affectus collegialis (es decir, la collegialitas affectiva) está siempre vigente, dice Juan Pablo II, y constituye la communio episcoporum. Pero ese affectus collegialis sólo se manifiesta como effectus collegialis (es decir, la collegialitas effectiva) sólo en algunos actos. Las diversas maneras en las que se actúa la colegialidad afectiva, con actos de colegialidad efectiva, son de orden humano, y concretan en grado diverso la exigencia divina de que el episcopado se exprese de modo colegial ${ }^{136}$.

Juan Pablo II traza un paralelismo entre la Iglesia una y universal, y por tanto indivisa, y el episcopado uno e indiviso, y por ende también de carácter universal. La mutua interioridad que hay entre la Iglesia universal y la Iglesia particular, por la cual la Iglesia universal existe in et ex las Iglesias particulares al tiempo que las Iglesias particulares existen in et ex la Iglesia universal, se reproduce en la relación entre el Colegio episcopal y cada uno de los Obispos. El Colegio episcopal, en cuanto elemento esencial de la Iglesia universal, es una realidad previa al oficio de presidir las Iglesias particulares, y la potestad del Colegio episcopal sobre toda la Iglesia es una realidad anterior a la de cada Obispo sobre su Iglesia particular. Y así como la Iglesia universal es una e indivisible, el Colegio episcopal, titular de la potestad suprema, una e indivisible, es un «sujeto teológico uno e indivisible»" ${ }^{137}$.

La mutua interioridad entre el Obispo que está al frente de una Iglesia particular y el Colegio episcopal en pleno se expresa de variadas maneras. El Obispo, en primer lugar, es el principio visible y fundamento de la unidad en la propia Iglesia particular. Además, el Obispo es el vínculo visible de comunión entre su Iglesia particular y la Iglesia universal, el punto de engarce de su Iglesia particular con la Iglesia universal, el testimonio visible de la presencia de la Iglesia universal en su Iglesia particular. Pero además, así como el Obispo representa su Iglesia particular en la comunión de las Iglesias, también representa la comunión de las Iglesias en su Iglesia particular. El

${ }^{135}$ Cf. Pastores gregis, n. 8.

${ }^{136}$ Cf. ibid. y Juan Pablo II, Discurso en la Clausura de la Asamblea general ordinaria del Sínodo de los Obispos, 29/10/1987, n. 4.

${ }^{137}$ Cf. Pastores gregis, n. 8. 
Obispo hace participar su portio Ecclesiae en la Iglesia universal, y al mismo tiempo hace presente la Iglesia universal en su portio Ecclesiae ${ }^{138}$.

El ministerio episcopal, entonces, tiene una dimensión universal, que corresponde al Colegio episcopal y su Cabeza como sujeto de la potestad episcopal suprema, y tiene una dimensión particular, que corresponde al Obispo en su Iglesia particular. La relación entre estas dos dimensiones del ministerio episcopal se establece por la comunión jerárquica, que es un principio constitutivo para el ejercicio de la autoridad episcopal. Juan Pablo II rescata algunos puntos firmes de la doctrina que deben tenerse en cuenta cuando se analiza la relación entre estas dos dimensiones del ministerio episcopal. En primer lugar, el Obispo diocesano tiene una potestad ordinaria, propia e inmediata necesaria para cumplir su ministerio pastoral, que constituye el ámbito propio para el ejercicio autónomo de su autoridad, que es tutelado por el derecho universal. Además, la potestad suprema corresponde al Romano Pontífice, y es también una potestad episcopal, ordinaria e inmediata sobre todas y cada una de Iglesias, las agrupaciones de las mismas y sobre todos los pastores y fieles. La unidad de la Iglesia radica en la unidad del episcopado. Así como existe una Cabeza del Colegio episcopal, el Romano Pontífice, también existe una Iglesia como Cabeza de las Iglesias, la de Roma. Tanto el Primado del Obispo de Roma como el Colegio episcopal son elementos propios de la Iglesia universal 'no derivados de la particularidad de las Iglesias', sino interiores a cada Iglesia particular, en la que está inmanente la Iglesia universal ${ }^{139}$.

Pero además del ámbito universal, hay muchas y variadas formas en que se puede expresar, y de hecho se expresa, la comunión episcopal y, por tanto, la solicitud por todas las Iglesias hermanas: en el seno de las Conferencias episcopales, de las Provincias y de las Regiones eclesiásticas. En todas esas ocasiones, los Obispos realizan sus acciones en el Colegio también cuando es realizada en las Conferencias episcopales. Todas esas acciones de los Obispos ponen en evidencia que cada Obispo es simultáneamente responsable, aunque lo sea de modos diversos, no sólo de la Iglesia particular que se le ha confiado, sino también de las Iglesias hermanas más cercanas y de la Iglesia universal ${ }^{140}$.

Sin embargo, es necesario señalar una diferencia, dice Juan Pablo II. En los Concilios particulares, que tienen una compleja composición en la que participan

\footnotetext{
${ }^{138}$ Cf. Pastores gregis, n. 55.

${ }^{139}$ Cf. Pastores gregis, n. 56.

${ }^{140}$ Cf. Pastores gregis, n. 59.
} 
miembros de todas las categorías de fieles del Pueblo de Dios, se manifiesta de modo inmediato no sólo la comunión entre los Obispos, sino también entre las Iglesias. Su fundamento teológico se encuentra de forma inmediata en la comunión de las Iglesias. Por esta razón son el momento adecuado para las decisiones más importantes. Las Conferencias episcopales, constituidas por la Santa Sede para que los Obispos ejerzan en ellos en forma conjunta algunas funciones pastorales, no pueden ocupar el puesto de los Concilios particulares, aunque sí pueden ser un instrumento valioso para la preparación de los Concilios plenarios. Ellas son hoy, además, un instrumento válido para expresar y poner en práctica el espíritu [indolem] colegial de los Obispos. El fundamento teológico de estas Conferencias episcopales se encuentra directamente en la dimensión colegial de la responsabilidad del gobierno episcopal, y sólo indirectamente en la comunión entre las Iglesias ${ }^{141}$.

\section{Directorio para el Ministerio Pastoral de los Obispos Apostolorum Successores}

Este Directorio, promulgado por la Congregación para los Obispos el 22 de febrero de 2004, que retoma, actualiza y completa el de $1973^{142}$, es un instrumento de carácter administrativo, cuya finalidad es determinar más detalladamente el modo que deben observar los Obispos en el cumplimiento de las leyes universales que se refieren al ejercicio de su ministerio ${ }^{143}$. Tiene la expresa intención de ser un instrumento útil para un ejercicio más orgánico y eficaz del complejo y difícil ministerio pastoral de los Obispos en la Iglesia de nuestro tiempo, tanto en el orden de la Iglesia particular, como en el servicio al bien de toda la Iglesia universal.

En este caso estamos ante un instrumento de carácter administrativo, producido por un Dicasterio de la Curia Romana, de naturaleza fundamentalmente pastoral y práctica, con indicaciones y directivas concretas para las actividades de los Obispos, que determina más detalladamente los modos de aplicación de las leyes universales que se refieren a su ministerio, y que

\footnotetext{
${ }^{141}$ Cf. Pastores gregis, nn. 62-63.

${ }^{142}$ Cf. Sagrada Congregación para los Obispos, Directorio para el ministerio Pastoral de los Obispos Ecclesiae imago, 22 de febrero de 1973, CELAM Bogotá $2000^{3}$.

${ }^{143} \mathrm{Cf}$. can. $31 \S 1$.
} 
expresamente deja a salvo la prudente discrecionalidad de los Obispos en su utilización ${ }^{144}$.

Dada la naturaleza propia de este documento, no encontramos en él afirmaciones novedosas en la línea doctrinal. Pero sí es interesante prestar atención al lugar que ocupan los párrafos dedicados a la tarea de los Obispos en los órganos supradiocesanos del ejercicio de su ministerio episcopal.

El Directorio Ecclesiae imago, después de presentar los principios fundamentales del ministerio episcopal, dedicaba sucesivamente tres capítulos a la función de los Obispos en la Iglesia universal, en la Iglesia particular y en las Conferencias episcopales. Pastores gregis, por su parte, después de un capítulo dedicado al misterio y ministerio del Obispo y otro a su vida espiritual, introducía tres capítulos dedicados respectivamente a su oficio de enseñanza, santificación y conducción, antes de ocuparse del servicio del Obispo a la comunión de las Iglesias, en cuyo contexto se describe su participación en las Conferencias episcopales.

El nuevo Directorio para el Ministerio Pastoral de los Obispos Apostolorum Successores, en cambio, después de un primer capítulo dedicado a la identidad y la misión del Obispo, en el segundo se ocupa de su solicitud por la Iglesia universal y la colaboración entre los Obispos. Un primer punto de este capítulo se dedica a la solicitud de cada Obispo por la Iglesia universal, y un segundo punto se ocupa de la cooperación de los Obispo entre sí y de los órganos supradiocesanos de colaboración, entre los que se encuentran las Conferencias episcopales.

Esta ubicación de la materia, sin cambiar en nada lo que el magisterio venía enseñando hasta el momento sobre la naturaleza teológica y los fundamentos de las Conferencias episcopales, sirve, sin embargo, para destacar la importancia que se le atribuye hoy a las mismas, que contribuyen de manera múltiple y fecunda a la actuación y al desarrollo del affectus collegialis entre los mismos del episcopado ${ }^{145}$.

\section{Conclusiones finales}

La comunión es la razón misma de ser de la Iglesia, querida por Dios como sacramento, es decir, signo e instrumento de la comunión de los hombres con

\footnotetext{
${ }^{144} C f$. Congregación para los Obispos, Directorio para le Ministerio Pastoral de los Obispos Apostolorum Successores, 22 de febrero de 2004, Vaticano 2004, Introducción, pág. 7.

${ }^{145}$ Cf. Apostolorum Successores, n. 28.
} 
Dios y de los hombres entre si $^{146}$. La Iglesia es precisamente este misterio de comunión que nace de la iniciativa de Dios, se realiza en el misterio pascual y se expande a través del tiempo y del espacio por la acción de la gracia divina y el ministerio de la Iglesia.

Las Conferencias episcopales, aunque no pertenezcan por su propia naturaleza a la constitución divina de la Iglesia, están sin embargo relacionadas con un elemento constitutivo e imprescindible de la misma. La Iglesia existió durante muchos siglos sin las Conferencias episcopales, pero no existió nunca sin la comunión, ya que ella es precisamente una comunión visible y sobrenatural, es decir, sacramental, de los hombres con Dios y de los hombres entre sí. Hoy las Conferencias episcopales resultan un instrumento útil para realizar, afianzar y acrecentar la comunión de la Iglesia. Por eso Juan Pablo II identifica esta comunión eclesial con la razón de ser y la finalidad primera de las Conferencias episcopales. Podría suceder que el día de mañana las Conferencias episcopales no resulten útiles o fueran menos eficaces para la construcción de la comunión eclesial, como hoy resultan menos prácticos algunos instrumentos de la comunión que en otros siglos fueron imprescindibles, como los Sínodos provinciales. En ese momento se podrá prescindir de las Conferencias episcopales, pero no podrá prescindirse de la comunión eclesial, y deberán surgir otros instrumentos que cubran la labor que hoy éstas realizan.

La profundización de la eclesiología de comunión, rescatada por el Concilio de una cierta sombra en la que había quedado para la teología de occidente, es, entonces, el marco adecuado para profundizar el estudio de la naturaleza eclesiológica de las Conferencias episcopales. Juan Pablo II da pistas firmes que invitan a realizar nuevos intentos de avanzar en la profundización de la naturaleza eclesiológica de las Conferencias episcopales, situándolas con relación a un elemento esencial de la Iglesia, como es la comunión.

Las Conferencias episcopales tendrán también un aspecto utilitario, ya que producen innumerables frutos en el orden de la realización del ministerio episcopal y de la misión de la Iglesia. Pero este sentido utilitario de las Conferencias episcopales no debe oscurecer, sino por el contrario iluminar el estudio de su naturaleza eclesial, para lo que resulta una clave preciosa la eclesiología de comunión.

${ }^{146}$ Cf. Lumen gentium, n. 1. 
El ministerio episcopal es por su misma naturaleza colegial, ya que los apóstoles fueron llamados a modo de colegio, con Pedro a la cabeza, y como colegio recibieron su misión de carácter universal ${ }^{147}$. Sus sucesores, los Obispos, mantienen la misma estructura colegial, con el Papa a la cabeza, ya que por su ordenación y con la comunión jerárquica son incorporados al colegio episcopal, sucesor del colegio apostólico. Por la ordenación episcopal el nuevo Obispo comienza a formar parte del colegio episcopal y de la misión universal que al mismo le corresponde.

El Obispo actúa siempre como un miembro del colegio episcopal, a condición de que mantenga su comunión jerárquica con el mismo. La misión canónica, por la que un Obispo recibe como oficio propio una parte de la misión de todo el colegio episcopal, no lo aísla del resto del colegio episcopal. Los demás Obispos, y todo el colegio episcopal, sigue teniendo parte en la misión que se le ha dado a uno de sus miembros a través de la misión canónica, y éste sigue relacionado con la misión de todo el colegio episcopal.

En este contexto se puede ubicar la insistencia con la que el beato Juan Pablo II se refirió siempre a las Conferencias episcopales como expresiones de la colegialidad episcopal. En ellas los Obispos ejercen juntos algunas funciones propiamente episcopales, que como tales pertenecen a todo el colegio episcopal. De esta manera las Conferencias episcopales se convierten en expresión de la colegialidad del colegio episcopal. Los elementos propios de la colegialidad episcopal se realizan en las Conferencias episcopales: el ejercicio de un ministerio propiamente episcopal, que es parte, por lo tanto, de la misión del colegio episcopal, a través de la acción conjunta de un grupo de Obispos, en comunión con el colegio episcopal y su cabeza. Es el iunctim, que menciona Juan Pablo II, de un grupo de miembros del colegio episcopal y su cabeza.

De todos modos, ya que ninguna Conferencia episcopal está formada por todos los miembros del colegio episcopal, sino sólo por algunos de ellos, la acción de una Conferencia episcopal no puede ser entendida como una acción del colegio episcopal propiamente dicho. Se debe aceptar, entonces, con Juan Pablo II, que la acción colegial de los Obispos a través de una Conferencia episcopal es una expresión parcial, limitada e incompleta de la colegialidad del colegio episcopal. Pero esto último de ninguna manera quita la naturaleza colegial de la acción conjunta de los Obispos a través de una Conferencia episcopal. La participación que cada Obispos tiene en la misión de todo

${ }^{147} C f$. Mt 28,18-20. 
el colegio episcopal, que es de naturaleza colegial, recibe una verdadera concreción práctica a través de su participación en la Conferencia episcopal, en la que los Obispos ejercen una responsabilidad estrictamente colegial, según el parecer de Juan Pablo II, sobre las Iglesias particulares que la integran.

Dado este origen de las Conferencias episcopales en la naturaleza misma del colegio episcopal, resulta comprensible la frecuencia con la que el Papa menciona los frutos de esta realización práctica de la colegialidad efectiva y afectiva de los Obispos, que redundan en una mayor eficacia de su ministerio. La realización de la colegialidad, elemento constitutivo del ministerio episcopal, en las Conferencias episcopales, está también indicándonos un camino para la comprensión de la naturaleza eclesiológica de las mismas. La comunión eclesial, que en su realización en el colegio episcopal se expresa en la colegialidad propia y constitutiva del ministerio episcopal y de la comunión jerárquica del colegio, es clave de bóveda para entender la naturaleza eclesiológica de las Conferencias episcopales, y también de su naturaleza canónica ${ }^{148}$.

Jesucristo fundó su Iglesia sobre el fundamento de los apóstoles. A ellos les confió la misión apostólica de hacer de todos los pueblos sus discípulos, bautizándolos y enseñándoles a cumplir todo lo que Él les había mandado, que debía extenderse hasta el fin de los tiempos, dándoles la potestad que necesitaban para llevarla a cabo ${ }^{149}$. Así los apóstoles, constituidos a modo de un Colegio, fueron enviados para llevar el misterio de la salvación a todos los hombres de todos los tiempos. El ejercicio, por lo tanto, de su misión apostólica, sucedida en el tiempo por la misión episcopal de la misma manera que el colegio episcopal sucede al colegio apostólico, tiene desde su origen una dimensión colegial, que se ha ido expresando a lo largo del tiempo de maneras muy variadas.

Ya en los primeros tiempos se dio un ejercicio propiamente colegial de la potestad con la que se ejerce la misión apostólica, cuando se reunió el llamado Concilio de Jerusalén, para responder a las preguntas e inquietudes que presentaba San Pablo con relación a la evangelización de los paganos ${ }^{150}$.

${ }^{148}$ De todo lo que se ha escrito sobre la colegialidad en relación a las Conferencias episcopales nos interesa citar en este lugar el trabajo de F. Guillemette, Les conférences épiscopales sontelles une institution de la collégialité épiscopale?, Studia Canonica 25/I (1991) 3976. El autor avanza con claridad y coherencia desde las enseñanzas del Concilio a la afirmación de la colegialidad existente en las Conferencias episcopales.

${ }^{149}$ Cf. Mt 28, 18-20.

${ }^{150} \mathrm{Cf}$. Hechos 15, 1-33. 
Durante los primeros siglos de la vida de la Iglesia surgieron espontáneamente reuniones de Obispos que se ajustaban en mayor o en menor medida a las estructuras organizativas del Imperio romano, y aparecieron así, los Concilios o Sínodos provinciales. En ellos los Obispos ejercían conjuntamente su función y su potestad episcopal, para el bien de todos los fieles de sus respectivas Iglesias particulares. Desde la primera mitad del siglo XIX los Obispos de una misma nación o territorio, erigidos como Conferencias episcopales por la Santa Sede, ejercen conjuntamente algunas funciones episcopales y, cuando han recibido la delegación de la Santa Sede, también la potestad episcopal, haciendo que sus decisiones, reconocidas por la autoridad suprema, resulten vinculantes para todos ellos y para los fieles de sus Iglesias particulares.

Está claro, entonces, que el affectus collegialis que une a todos los Obispos por su pertenencia al Colegio episcopal y su unión con su cabeza, el Papa, se expresa como effectus collegialis no sólo en las acciones que realiza todo el Colegio, sino también, aunque de manera parcial, cuando un grupo de ellos concretan su acción ministerial y potestativa sobre las Iglesias particulares que se les han confiado, siempre dentro de los límites precisos de la misión que se les ha confiado. Por lo tanto, teniendo siempre en cuenta que sólo el Colegio episcopal en pleno podrá ser titular de un ejercicio estrictamente colegial del ministerio episcopal, ya sea en forma solemne a través de un Concilio ecuménico o de manera simple con los Obispos dispersos por el mundo y convocados a una acción colegial por el Papa o al menos con su posterior reconocimiento, habrá que considerar que también el ejercicio conjunto de algunas funciones episcopales, e incluso de la potestad episcopal que un grupo de Obispos hacen sobre los fieles que se le han encomendado, por ejemplo con el encargo hecho a las Conferencias episcopales de tomar algunas determinaciones vinculantes para todos sus miembros y los respectivos fieles, tienen la naturaleza propia y son la expresión del carácter colegial del ministerio episcopal.

A la luz de la fructífera tarea que las Conferencias episcopales vienen realizando desde hace ya casi dos siglos, y teniendo en cuenta que son una expresión contingente pero hoy muy efectiva de un elemento constitutivo de la Iglesia, como lo es la comunión y su expresión episcopal, que es la colegialidad, es posible esperar que seguirán prestando a la Iglesia el fructífero servicio que prestan, de formas variadas, desde su origen. Sin duda la experiencia personal, además de su propia sabiduría, fueron los pilares en los que pudo apoyarse el beato Juan Pablo II para impulsar y hacer avanzar no sólo el magisterio sino 
también la legislación sobre las Conferencias episcopales, como instrumentos de la comunión eclesial y expresión viva, en lo medida que les corresponde, de la colegialidad episcopal.

\section{Bibliography}

Antón A., Conferencias episcopales, ¿instancias intermedias?, Salamanca 1989.

Antón A., Gregorianum 80 (1999) 263-297.

Arrieta J. I., Le conferenze episcopali nel motu proprio Apostolos Suos, Ius Ecclesiae XI (1999) 169-191.

Bunge A., Precisiones jurídicas sobre las funciones de las Conferencias episcopales. Aportes del magisterio de Juan Pablo II, Buenos Aires, EDUCA 1996.

Feliciani G., Il potere normativo delle Conferenze episcopali nella comunione ecclesiale, en: ME 116 (1991) 87-93.

Feliciani G., Le Conferenze episcopali, Bolonia 1974.

Ghiralda G., y Urrutia F., Conferentiae Episcoporum et Munus docendi, Romae 1987.

Guillemette F., Les conférences épiscopales sontelles une institution de la collégialité épiscopale?, «Studia Canonica» 25 (1991) 3976.

Manzanares J., La autoridad doctrinal de las Conferencias episcopales, en AA-Vv., Naturaleza y futuro de las Conferencias episcopales. Actos del Coloquio internacional de Salamanca, 3-8 de enero de 1988, Salamanca 1988, págs. 289-321.

Manzanares J., Reflexiones sobre el documento "Estatuto teológico y jurídico de las Conferencias episcopales”, REDC 46 (1989) 189202.

Messori V., Ratzinger J., Rapporto sulla fede, Milano 1985.

Monterisi F., Intervento del Segretario della Congregazione per i Vescovi, en: L'Osservatore Romano del 24 luglio 1998, pág. 7.

Ratzinger J., Intervento del Prefetto della Congregazione per la Dottrina della Fede, en: L'Osservatore Romano del 24 luglio 1998, pág. 1.

Villar J., R., La naturaleza de las Conferencias episcopales y la Carta Apostolos Suos, "Scripta Theologica" XXXI (1999) 115-137. 